Document downloaded from:

http://hdl.handle.net/10251/47506

This paper must be cited as:

Corberán, JM.; Finn, D.; Montagud, C.; Murphy, F.; Edwards, K. (2011). A quasi-steady state mathematical model of an integrated ground source heat pump for building space control. Energy and Buildings. 43(1):82-92. doi:10.1016/j.enbuild.2010.08.017.

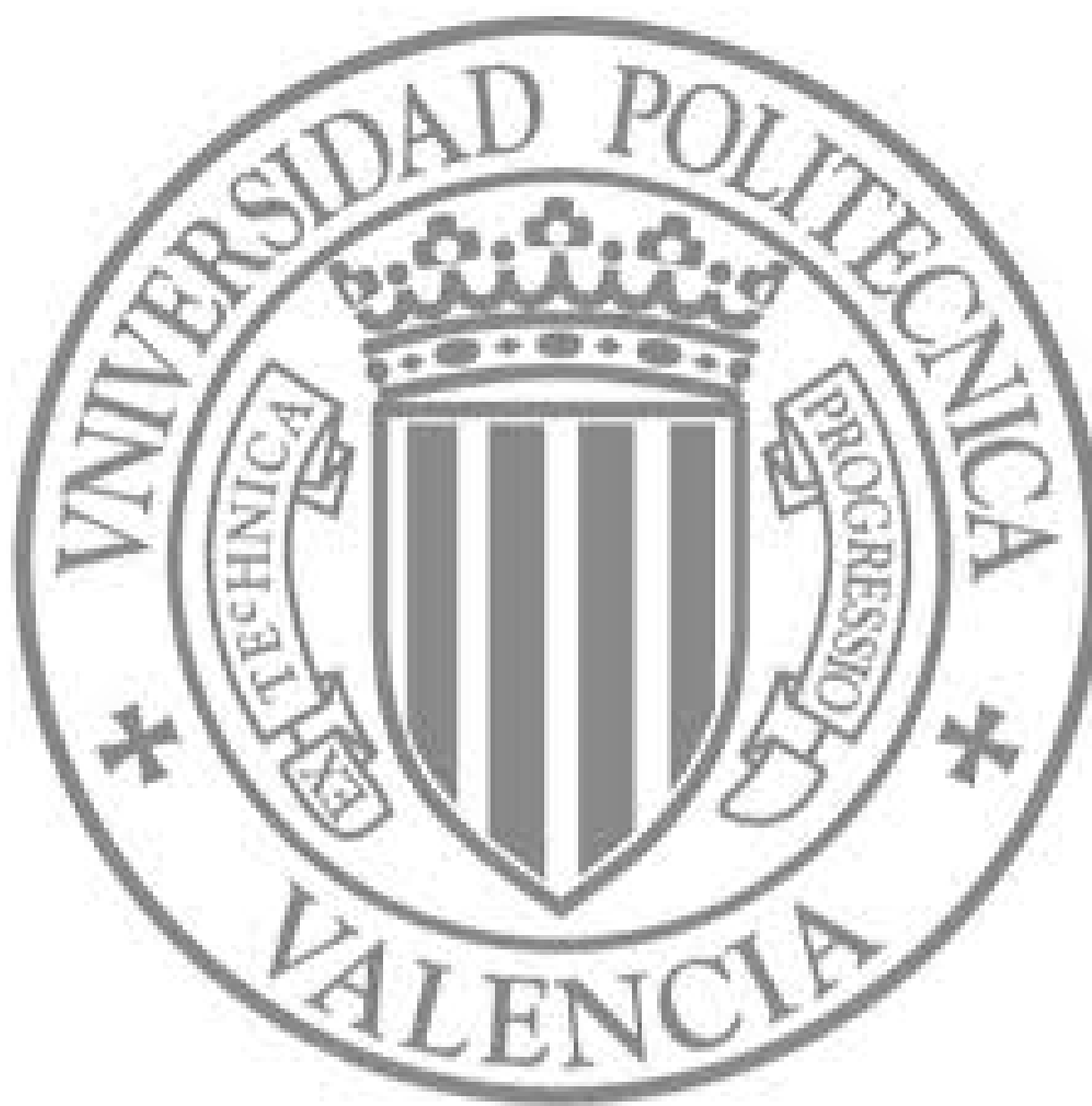

The final publication is available at

http://dx.doi.org/10.1016/j.enbuild.2010.08.017

Copyright Elsevier 


\section{Elsevier Editorial System(tm) for Energy and Buildings}

Manuscript Draft

Manuscript Number: ENB-D-10-00098R2

Title: A Quasi-Steady State Mathematical Model of an Integrated Ground Source Heat Pump for Building Space Control

Article Type: Full Length Article

Keywords: Ground Source Heat Pump, Mathematical Model, Control Sensitivity Study, Optimisation Analysis

Corresponding Author: Dr. Donal P. Finn, PhD, MEngSc, BE

Corresponding Author's Institution: University College Dublin

First Author: Jose M Corbéran, PhD

Order of Authors: Jose M Corbéran, PhD; Donal P Finn, PhD; Carla M Montagud, Dip.Ing; Fintan T

Murphy, BE, MEngSc; Kilian C Edwards, BEng

Abstract: This paper is concerned with the development of a mathematical model, capable of describing the quasi steady state performance of an integrated ground source heat pump, which is used for heating and cooling of an institutional building located in a Mediterranean climate. The model is structured on functional basis according to the heat pump vapour compression or primary circuit, a secondary ground loop circuit and a secondary building loop circuit. Heat pump heating and cooling capacities, as well as COP, are considered to be dependent variables and are estimated in the model using performance fitted maps. Independent variables include: compressor speed, circulation pump speeds, ground loop return temperature and building circuit return temperature. The model is validated using data from a full scale ground source heat pump installation. The validated model is used to examine system capacity and performance sensitivity to different control optimisation strategies, including set-point control of room air temperature, room air bandwidth temperature, building loop return water temperature and building loop return bandwidth temperature. 


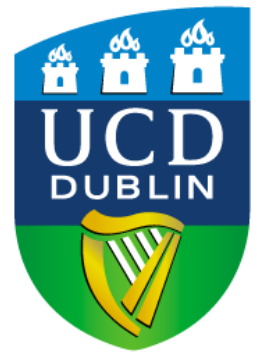

UCD School of Electrical, Electronic and Mechanical Engineering

University College Dublin, Belfield, Dublin 4, Ireland

$T+3531716$ 1884/1787/1909

$F+35312830534 / 2830921$
Scoil na hInnealtóireachta Leictrí, Leictreonaí agus Meicniúla UCD

08 July 2010

Prof. Branislav Todorovic,

Editor

Energy and Buildings

Ms. Ref. No.: ENB-D-10-00098

\title{
A Quasi-Steady State Mathematical Model of an Integrated Ground Source Heat Pump for Building Space Control
}

\author{
J.M. Corberan*, D.P. Finn ${ }^{+}$, C.M. Montagud*, F.T. Murphy ${ }^{+}$and K.C. Edwards ${ }^{+}$ \\ "Escuela Técnica Superior de Ingenieros Industriales, \\ Universidad Politécnica de Valencia, Spain \\ + School of Electronic, Electrical \& Mechanical Engineering, \\ University College Dublin, Dublin, Ireland
}

Dear Prof. Todorovic,

Please find attached our further revised paper. We have included some additional references as per your email of June $15^{\text {th }}$ and we have also addressed the question of the reviewer (see next page). We hope this addresses the issues raised.

Yours sincerely

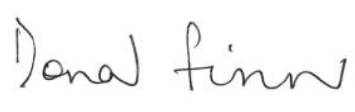

Donal Finn, PhD

Senior Lecturer

University College Dublin 
- - - - Original Message--.--

From: ees.enb.0.9b723.23deadc7@eesmail.elsevier.com

[mailto:ees.enb.0.9b723.23deadc7@eesmail.elsevier.com] On Behalf of Energy and Buildings

Sent: 15 June 2010 17:22

To: donal.finn@ucd.ie

Subject: Your Submission

Editors comments:

Dear Sir,

I missed to write my remarks and suggestions. First you have 18 figures and 3 tables.

Please imagine how each figure would look after being published, published in black and white and a maybe being reduced in the size. Hour in international system is only $\mathrm{h}$ not $\mathrm{hr}$. I also noticed that among references there is no one concerning papers we published in our journal, and we had a lot. We recommend to put in references these papers, not to be impression of the potential readers that our journal never wrote anything about the problem you are treating. Please, be so kind and go through our previous issues and be informed what we published. And please add in the references. It is important to give some link and contiunation with our previously published papers.

Regards, B.Todorovic, editor.

Reviewers' comments:

Reviewer \#1: I recommend reviewing the reported overall heat transfer coefficient (U) associated with the conditioned space. Please note that the value of $U$ is usually less than $1.0 \mathrm{~W} \cdot \mathrm{m}-2 \mathrm{~K}-1$. Could be $1.7 \mathrm{~W} . \mathrm{m}-2 \mathrm{~K}-1$. instead of reported $17 \mathrm{~W} . \mathrm{m}-$ $2 \mathrm{~K}-1$ ? 


\title{
Ms. Ref. No.: ENB-D-10-00098 \\ A Quasi-Steady State Mathematical Model of an Integrated Ground Source Heat Pump for Building Space Control
}

\begin{abstract}
J.M. Corberan*, D.P. Finn ${ }^{+}$, C.M. Montagud ${ }^{*}$, F.T. Murphy ${ }^{+}$and K.C. Edwards ${ }^{+}$
"Escuela Técnica Superior de Ingenieros Industriales, Universidad Politécnica de Valencia, Spain + School of Electronic, Electrical \& Mechanical Engineering, University College Dublin, Dublin, Ireland
\end{abstract}

KEY

SECOND AMMENDMENTS July 2010

BLACK : Reviewer Comment

RED: Author response

BLUE: Paper modification

Additional clarification was sought on the building $U$ value and load.

The following section has been added which hopefully clarifies the point raised by the reviewer. We are sorry for any confusion caused.

The $U$ values utilised in the model for the building external walls and windows were $0.6 \mathrm{~W} \cdot \mathrm{m}^{-2} \mathrm{~K}^{-1}$ and $5.75 \mathrm{~W} \cdot \mathrm{m}^{-2} \mathrm{~K}^{-1}$ respectively. By considering all thermal loads to include fabric gains, solar gains, internal gains, infiltration and ventilation loads, a peak design load normalised with respect to floor area, with an external design temperature of $35^{\circ} \mathrm{C}$ and internal set-point temperature of $23.5^{\circ} \mathrm{C}$, was determined to be $102 \mathrm{~W} \cdot \mathrm{m}^{-2}$.

The Editor of Energy and Buildings asked that additional references be included.

Four additional references have been included as follows:

[8] Renedo, C.J, et al. (2006), 'Optimum design for reversible water-water heat pumps', Energy and Buildings, 38, 1240-1247.

[9] Liu , X Hong, T. (2010) 'Comparison of energy efficiency between variable refrigerant flow systems and ground source heat pump systems' Energy and Buildings, 42, 584-589.

[13] Chen, Y. (2000), 'Real-time predictive supervisory operation of building thermal systems with thermal mass', Energy and Buildings, 33, 141-150.

[14] Guo, W, Nutter, D. W. (2010), 'Setback and setup temperature analysis for a classic doublecorridor classroom building', Energy and Buildings, 42, 189-197.

The following additional text has been added to the body of the paper

The primary difference between ground and air-source heat pumps can be attributed to the external source. GSHPs offer relatively constant operating parameter for short term measurements insuring a smaller temperature difference between the condenser and evaporator when compared to ASHPs [8]. In a study by Liu and Hong [9] an air source heat pump with variable compressor control was compared to a GSHP with on/off control. The GSHP was shown to be more efficient than the ASHP especially at high heating loads, but less so at part loads. Chen [13] and Guo and Nutter [14] also studied optimal zone set-point temperatures for heating and cooling to improve system performance.

The Editor of Energy and Buildings asked that that the colour of the diagrams be evaluated so that the paper can be easily understood in the B\&W print version.

The diagrams have amended so they are more easily understood in B\&W. 
KEY

BLACK : Reviewer Comment

RED: Author response

BLUE: Paper modification

Reviewer \#1: The general scientific level of the paper is good to very good. The paper deals with an actual problem focusing on energy optimisation practical issues on a basis of an experimental and numerical approach.

\section{Recommendations}

A comment should be given on how the energy efficiency of the building could have impact on the obtained results.

A comment is included in the conclusions on this issue (given below). The authors acknowledge that many factors will influence the heat pump performance including, heat pump selection (and the choice of compressor therin), ground loop design, building hydronic loop design and building design and efficiency. However within the constransts of the current paper it has not been possible to consider these issues.

Finally, it should be noted that overall system performance will be influenced by many other factors including heat pump design, ground loop design, building hydronic loop design and building efficiency. However the influence of these issues on overall system performance were not explored in the current paper.

Building heating and cooling loads values are estimated in a very simple manner given that they do not consider solar gains (office are East orientated!) nor energy losses/gains associated to infiltration/ventilation rates. Also, the value of the $U$ is not specified (Eq. 20)!

A short section has been added at the end of Section 4.3 that addresses this issue. It is as follows:

The $\mathrm{U}$ values utilised in the model for the building external walls and windows were $0.6 \mathrm{~W} \cdot \mathrm{m}^{-2} \mathrm{~K}^{-1}$ and $5.75 \mathrm{~W} . \mathrm{m}^{-2} \mathrm{~K}^{-1}$ respectively. By considering all thermal loads to include fabric gains, solar gains, internal gains, infiltration and ventilation loads, a peak design load normalised with respect to floor area, with an external design temperature of $35^{\circ} \mathrm{C}$ and internal set-point temperature of $23.5^{\circ} \mathrm{C}$, was determined to be $102 \mathrm{~W} \cdot \mathrm{m}^{-2}$.

The results shown in Figure 9 need to be more explicit in terms of assumptions. For instance, why not show the ambient temperature in free-floating regime in the same graphic?

Figure 9 has been modified to indicate the ambient temperature.

To turn out the presentation more explicit, I recommend moving the first paragraph of the introduction next to the last paragraph and reformulate. After the review, the introduction would start with the state of the art and end with an outline of the paper objectives and methods under these circumstances.

This has been done as suggested. The final paragraph now reads as follows: 
This paper examines, for a ground source heat pump (GSHP), how control of building circuit variables affects overall system performance. Building integrated ground source heat pumps usually incorporate two secondary circuits; an indoor hydronic circuit for heating or cooling of a building and an outdoor circuit, which is typically either a horizontal or vertical ground loop heat exchanger. This work focuses on a sensitivity study, considered from a system control perspective and which examines the role of various building circuit variables. The research was carried out by means of a system mathematical model, developed as part of this research, which incorporates a heat pump model, a building secondary loop model and a simple building space model. The various mechanical components (heat pump, circulation pumps and fan coils) were individually modelled and incorporated in an overall system model, which was validated by comparison to system experimental data from an institutional building located in a Mediterranean climate. Variables analysed include building hydronic circuit set-point temperature, building circuit hydronic temperature bandwidth, building space set-point temperature and building space temperature bandwidth.

I also recommend reviewing some other general aspects of the manuscript:

- the nomenclature appears not to include all variables. Although familiar to the target scientific audience, SPF, COP, UA, etc. might need to appear as well...

COP, SPF and UA have been included in the nomenclature

- Vwater in addition of not being included in the nomenclature, appears with capital letter in Eqs. 11 to 13, whereas in the remaining (13 and 14) is lowercase letter...

V (velocity) has been included in the nomenclatuire and the anomaly corrected.

- the cooling thermal load appears in italic in nomenclature whereas in the body is normal.

This anomaly has been corrected.

- Celsius degrees symbol is oC and not simply C.

This anomaly has been corrected throughout.

- Mc is described as "water flow rate" in body text (page 4) while in nomenclature $M$ is used for describing "mass". Mc is in fact a mass flow rate such as defined right above the $M$ symbol in nomenclature and by Vce and Vci elsewhere in the text.

These anomalies have been corrected. In order to avoud confusion, Mc has been removed from the Nomenclature and is explicitly defined for Fig 2 as follows:

Fig. 2. Validation of IMST-ART heat pump model for different evaporator and condenser flow rates [15]. (Note: $\mathrm{Mc}=$ Condenser water mass flow rate $\mathrm{kg} \cdot \mathrm{hr}^{-1}$ )

- where appears Yang and Pedersen (page 4) should be Yang et al. according to references.

This anomaly has been corrected. 



\title{
A Quasi-Steady State Mathematical Model of an Integrated Ground Source Heat Pump for Building Space Control
}

\author{
J.M. Corberan*, D.P. Finn ${ }^{+}$, C.M. Montagud*, F.T. Murphy ${ }^{+}$and K.C. Edwards ${ }^{+}$ \\ *Escuela Técnica Superior de Ingenieros Industriales, \\ Universidad Politécnica de Valencia, Spain \\ + School of Electronic, Electrical \& Mechanical Engineering, \\ University College Dublin, Dublin, Ireland
}

\begin{abstract}
This paper is concerned with the development of a mathematical model, capable of describing the quasi steady state performance of an integrated ground source heat pump, which is used for heating and cooling of an institutional building located in a Mediterranean climate. The model is structured on functional basis according to the heat pump vapour compression or primary circuit, a secondary ground loop circuit and a secondary building loop circuit. Heat pump heating and cooling capacities, as well as COP, are considered to be dependent variables and are estimated in the model using performance fitted maps. Independent variables include: compressor speed, circulation pump speeds, ground loop return temperature and building circuit return temperature. The model is validated using data from a full scale ground source heat pump installation. The validated model is used to examine system capacity and performance sensitivity to different control optimisation strategies, including set-point control of room air temperature, room air bandwidth temperature, building loop return water temperature and building loop return bandwidth temperature.
\end{abstract}




\section{Nomenclature}

A

$\mathrm{C}_{\mathrm{p}}$

$\mathrm{COP}$

$\mathrm{F}_{\mathrm{REQ}}$

$\dot{\mathrm{m}}$

$\mathrm{M}$

$\mathrm{P}$

$\dot{\mathrm{P}}$

$\dot{\mathrm{Q}}$

SPF

$T$

$\mathrm{T}_{\mathrm{RCI}}$

$\mathrm{T}_{\mathrm{RCE}}$

$\mathrm{t}$

U

UA

$\mathrm{V}$

$\mathrm{V}$

$\mathrm{V}_{\mathrm{CI}}$

$\mathrm{V}_{\mathrm{CE}}$

$\dot{\mathrm{V}}$

$\Delta \mathrm{t}$

$\Delta \mathrm{x}$ heat transfer surface area $\left(\mathrm{m}^{2}\right)$

specific heat capacity at constant pressure $\left(\mathrm{J}^{\mathrm{kg}} \mathrm{kg}^{-1} \mathrm{~K}^{-1}\right)$

Coefficient of performance

circulation pump frequency $(\mathrm{Hz})$

mass flow rate $\left(\mathrm{kg} . \mathrm{s}^{-1}\right)$

mass $(\mathrm{kg})$

perimeter $(\mathrm{m})$

power (W)

heat transfer rate $(\mathrm{W})$

seasonal performance factor

temperature $\left({ }^{\circ} \mathrm{C}\right)$

water return temperature for the building circuit $(\mathrm{K})$

water return temperature for the external circuit $(\mathrm{K})$

time (s)

overall heat transfer coefficient $\left(\mathrm{W} \cdot \mathrm{m}^{-2} \mathrm{~K}^{-1}\right)$

$\mathrm{UA}$ value $\left(\mathrm{W} \cdot \mathrm{K}^{-1}\right)$

velocity $\left(\mathrm{m} \cdot \mathrm{s}^{-1}\right)$

volume $\left(\mathrm{m}^{3}\right)$

water mass flow rate in the internal circuit $\left(\mathrm{kg} \cdot \mathrm{s}^{-1}\right)$

water mass flow rate in the external circuit $\left(\mathrm{kg} . \mathrm{s}^{-1}\right)$

volumetric flow rate $\left(\mathrm{m}^{3} \cdot \mathrm{s}^{-1}\right)$

time step

distance between two consecutive nodes

Greek symbols

$\varepsilon \quad$ heat exchanger effectiveness

$\rho$ density $\left(\mathrm{kg} . \mathrm{m}^{-3}\right)$

Subscripts

c cooling

FC fan coil

HP heat pump

ICP internal circulation pump

i inlet

o outlet

SYSTEM heat pump, fan coils, internal pump, external pump 


\section{Introduction}

Research concerning control issues related to vapour compression systems has largely focused on refrigeration and air-conditioning and to a lesser extent on heat pumps. Considering refrigeration and air-conditioning systems, reported research has examined various capacity regulation techniques including compressor modulation by speed control, on/off cycling, as well as modulation using tandem compressors $[1,2$, 3]. Control related research has focused on optimisation of evaporator and expansion valve operation through superheat control and regulation $[4,5]$. Other capacity control techniques such as clearance volume control, suction pressure control, cylinder unloading, back-pressure and discharge gas bypass regulation, although reported in the literature, appear to have been less commonly deployed in commercial systems [6, 7]. The primary difference between ground and air-source heat pumps can be attributed to the external source. GSHPs offer relatively constant operating parameter for short term measurements insuring a smaller temperature difference between the condenser and evaporator when compared to ASHPs [8]. In a study by Liu and Hong [9] an air source heat pump with variable compressor control was compared to a GSHP with on/off control. The GSHP was shown to be more efficient than the ASHP especially at high heating loads, but less so at part loads.

Research to date on control of ground source heat pumps has focussed on capacity control issues and to a lesser extent on control of secondary side working fluids. The most common type of capacity control currently deployed in commercial ground source heat pumps appears to be on/off compressor cycling [2]. Karlsson and Fahlen [10] compared on/off compressor control with variable speed control for a brine-towater heat pump. They noted that the main benefit of using a variable speed compressor was a reduction in the need for supplementary heating. In another study, Karlsson and Fahlen reported that heat pumps are generally sized to match $60 \%$ of the heating load [11]. Control was achieved using either on/off cycling, when operating at part load conditions, or by supplemental heating when demand exceeds the heat pump capacity. Karlsson and Fahlen examined intermittent control and variable-speed capacity control by comparing the performance of two capacity-controlled heat pumps and one standard heat pump with a single-speed compressor. Test data was then used for seasonal performance factor (SPF) calculations. The SPF calculations indicated that despite improved performance at part load, the variable-speed controlled heat pump did not necessarily improve the annual efficiency compared with the intermittently operated heat pump. Zhao et al. [12] examined the use of variable speed compressors in small scale geothermal heat pumps. COP was observed to increase as the heat sink temperature decreased, at a constant compressor frequency. For sink temperatures of $30^{\circ} \mathrm{C}$ and $35^{\circ} \mathrm{C}$, an increasing trend of COP with decreasing frequency was observed. Lower frequencies reduced the refrigerant flow rate in the evaporator and condenser, which allowed more time for the refrigerant to exchange heat with the secondary fluid. This reduced the associated mean temperature differences between the refrigerant and the secondary fluids in each heat exchanger. The difference between the saturation temperatures (and pressures) of the evaporator and condenser were therefore reduced. Chen [13] and Guo and Nutter [14] also studied optimal zone set-point temperatures for heating and cooling to improve system performance.

Yang et.al. [15] created a mathematical model of an under-floor heat pump system. The model was used to assess system performance with different controllers, namely; 
P, PID and PID with pre-filtering of inputs, and relay (on/off control) for controlling the heat pump capacity. The use of a PID pre-filtering controller with a variable speed compressor was predicted to reduce power consumption, when compared to the relay type control. This model does not appear to take into account the inefficiencies inherent in variable speed compressors, such as the inverter and motor efficiency at part load.

This paper examines, for a ground source heat pump (GSHP), how control of building circuit variables affects overall system performance. Building integrated ground source heat pumps usually incorporate two secondary circuits; an indoor hydronic circuit for heating or cooling of a building and an outdoor circuit, which is typically either a horizontal or vertical ground loop heat exchanger. This work focuses on a sensitivity study, considered from a system control perspective and which examines the role of various building circuit variables. The research was carried out by means of a system mathematical model, developed as part of this research, which incorporates a heat pump model, a building secondary loop model and a simple building space model. The various mechanical components (heat pump, circulation pumps and fan coils) were individually modelled and incorporated in an overall system model, which was validated by comparison to system experimental data from an institutional building located in a Mediterranean climate. Variables analysed include building hydronic circuit set-point temperature, building circuit hydronic temperature bandwidth, building space set-point temperature and building space temperature bandwidth.

\section{System Description}

The GSHP system utilised in this research is located in an institutional building at the Universidad Politécnica de Valencia, Valencia, Spain. The overall heat pump system consists of a heat pump, an indoor circuit and an outdoor circuit as shown in Fig. 1(a).

\subsection{Ground Source Heat Pump}

The heat pump, a prototype unit, is a water-to-water reversible GSHP, which uses propane (R290) as its primary refrigerant. The nominal heating and cooling capacities are $18 \mathrm{~kW}\left(45^{\circ} \mathrm{C}\right.$ return $/ 16^{\circ} \mathrm{C}$ return) and $14 \mathrm{~kW}\left(30^{\circ} \mathrm{C}\right.$ return $/ 12^{\circ} \mathrm{C}$ return) respectively. The outdoor loop consists of a ground source heat exchanger (GSHX), which is coupled to the heat pump by an external hydronic loop. The GSHX itself consists of six vertical boreholes connected in a balanced parallel configuration. Each borehole has a depth of $50 \mathrm{~m}$ and contains a single polyethylene $U$ tube of $25 \mathrm{~mm}$ diameter bore, with a $70 \mathrm{~mm}$ separation between the upward and downward tubes. The borehole overall diameter is $150 \mathrm{~mm}$. The six boreholes are arranged in a $2 \times 3$ rectangular grid $\left(18 \mathrm{~m}^{2}\right)$, with a $3 \mathrm{~m}$ separation between boreholes.

\subsection{Building Description}

The building (see Fig. 1(b)) which is heated and cooled, comprises approximately $250 \mathrm{~m}^{2}$ floor area and includes a corridor, nine offices (located on the east façade of the building), a computer room and a service room with office equipment and other internal loads. The building loop consists of a series of 12 parallel connected fan coils, an internal hydronic loop and a water storage tank (160 L). Each office, along with the service room, is equipped with one fan coil, except for the computer room which 
has two installed fan coils. The corridor does not have a fan coil unit present. Each fan coil can be individually regulated by means of a thermostat and comfort temperature and fan speed can be selected by the user. The control for each fan coil is governed by a three way valve that allows the heating/cooling water to be modulated through the fan coil. The valve is controlled by the thermostat of the room.

Fig. 1. GSHP system (a) GSHP system schematic (b) Building plan

\subsection{System Control Components}

The operation of the heat pump is governed by an electronic controller which, depending on the building water return temperature, switches on/off the heat pump compressor. The default values for the building circuit return temperatures are between $37^{\circ} \mathrm{C}$ and $43^{\circ} \mathrm{C}$ for heating mode and $12^{\circ} \mathrm{C}$ and $15^{\circ} \mathrm{C}$ for cooling mode. The ground circulation pump is controlled by the heat pump controller, which activates the external pump 60 seconds before compressor activation. When the compressor switches off, the external pump continues to operate for a further period of one minute. A timer controls overall system operation, which was programmed to operate between 0700 and 2100 hours, 5 days per week. Finally, in order to vary the fan coil and GSHX water flow rates, two frequency inverters were installed, one for each circulation pump.

\subsection{Instrumentation and Data Acquisition System}

Pt100 RTD devices are used to measure the inlet and return temperature for each hydronic circuit. The mass flow rate for each circuit is measured by means of a coriolis meter. The power consumption associated with the compressor and external pump, the internal pump and fan coils are measured by two separate power meters. The data acquisition system is programmed, such that the power consumption of each individual component, i.e., the internal circulation pump, the external circulation pump, the fan coils and the heat pump compressor unit, can be calculated from the data collected by the two power consumption meters. Climatic data is collected using a meteorological station located on the building roof such that air temperature, air humidity, wind speed and solar irradiation are recorded every five minutes. The data acquisition system has been in operation for a period in excess of 24 months prior to the current work [16].

\section{Methodology}

A system level mathematical model was developed from the GSHP heat pump system using Engineering Equation Solver (EES) [17]. The vapour compression software package IMST-ART was used to model the behaviour of the GSHP as a standalone system [18]. In order to do this, parametric data associated with the compressor, condenser, expansion valve and evaporator was utilised within IMST-ART to model the performance of the heat pump. The IMST-ART model of the heat pump was validated using experimental data. Sensitivity studies using the validated IMST-ART heat pump model facilitated the production of system performance maps of heat pump capacity and compressor power consumption as a function of building and ground water return temperatures for different mass flow rates. These heat pump performance maps were correlated using polynomial equation fits, which were incorporated within 
the EES system mathematical model, along with separate pump and fan coil performance maps, which were also integrated into the EES model. The overall system model was then validated against data from the full UPV GSHP system. The validated model is used to examine system capacity and performance sensitivity with different control strategies, including set-point control of room air temperature, room air temperature bandwidth, building loop return water temperature and building loop return temperature bandwidth.

\section{System Mathematical Model}

\subsection{Heat Pump Model: IMST-ART Model and Experimental Validation}

The IMST-ART heat pump model incorporates the key elements of the vapour compression circuit including the evaporator, condenser, compressor, expansion valve and connecting pipe work. Using IMST-ART, the heat pump model was constructed on a component by component basis, thereby allowing validation between the IMSTART predictions and experimental test data, as shown in Fig. (2). By constraining condenser and evaporator water inlet temperatures to be $10.8^{\circ} \mathrm{C}$ and $22^{\circ} \mathrm{C}$ respectively and considering three condenser water mass flow rates (2000, 2300 and $\left.2600 \mathrm{~kg} \cdot \mathrm{h}^{-1}\right)$ in conjunction with five evaporator water mass flow rates (2000, 2300, 2600, 3100 and $4200 \mathrm{~kg} \cdot \mathrm{h}^{-1}$ ), five data points were obtained for each condenser mass flow rate condition. Comparison between the experimental results and IMST-ART predictions for these mass flow rate permutations show that cooling capacity and COP of the heat pump were within a $\pm 2.5 \%$ error band [19]. Elsewhere, other more general validation studies of IMST-ART demonstrated maximum error bands of less than $\pm 4 \%$ for a wider range of operating conditions where other heat pump systems were modelled [20].

Fig. 2. Validation of IMST-ART heat pump model for different evaporator and condenser flow rates [19]. (Note: $\mathrm{Mc}=$ Condenser water mass flow rate $\mathrm{kg} \cdot \mathrm{h}^{-1}$ )

\subsection{IMST ART Performance Maps and Correlations}

Using the IMST-ART software package, a performance map describing the sensitivity of heat pump capacity and power consumption subject to variation in external and internal water mass flow rates $\left(\mathrm{V}_{\mathrm{CE}}, \mathrm{V}_{\mathrm{CI}}\right)$ and external and internal water return temperatures $\left(\mathrm{T}_{\mathrm{RCE}}, \mathrm{T}_{\mathrm{RCI}}\right)$ was made. This was carried out for five different pump speeds $(20,30,40,50,60 \mathrm{~Hz})$ for both heating and cooling modes. In cooling mode, five different internal (building) water return temperatures $\left(\mathrm{T}_{\mathrm{RCI}}\right)\left(8,10,12,14,16^{\circ} \mathrm{C}\right)$ and five different external return temperatures $\left(\mathrm{T}_{\mathrm{RCE}}\right)\left(23,24,25,26,27^{\circ} \mathrm{C}\right)$ were examined. In heating mode, the internal water return temperatures examined were 45 , $42.5,40,38,36^{\circ} \mathrm{C}$ and the external return temperatures consisted of $20,17.5,15,12.5$ and $10^{\circ} \mathrm{C}$. In total, this gave rise to 125 data points for each mode. Using this data, correlations for heating and cooling mode, were established as follows:

$$
\begin{aligned}
& \dot{\mathrm{Q}}_{\text {evaporator }}=f\left(\mathrm{~V}_{\mathrm{Cl}}, \mathrm{V}_{\mathrm{CE}}, \mathrm{T}_{\mathrm{RCl}}, \mathrm{T}_{\mathrm{RCE}}\right) \\
& \dot{\mathrm{Q}}_{\text {condenser }}=f\left(\mathrm{~V}_{\mathrm{Cl}}, \mathrm{V}_{\mathrm{CE}}, \mathrm{T}_{\mathrm{RCl}}, \mathrm{T}_{\mathrm{RCE}}\right) \\
& \dot{\mathrm{P}}_{\mathrm{HP}}=f\left(\mathrm{~V}_{\mathrm{Cl}}, \mathrm{V}_{\mathrm{CE}}, \mathrm{T}_{\mathrm{RCl}}, \mathrm{T}_{\mathrm{RCE}}\right)
\end{aligned}
$$


where the water mass flow rates $\left(\mathrm{V}_{\mathrm{CI}}, \mathrm{V}_{\mathrm{CE}}\right)$ are expressed in $\mathrm{kg} . \mathrm{s}^{-1}$, the water return temperatures are expressed in degrees Kelvin $(\mathrm{K})$, the heat transfer capacities and the power consumption are in Watts (W). Polynomial correlations, given by Eqs. (4) to (9), were obtained by means of a quadratic regression curve fitting to the data with regression values $\mathrm{R}^{2}$ equal to or better than 0.998 .

\section{Cooling Mode Correlations}

$\dot{Q}_{\text {evaporator }}=A_{0}+\left(A_{1} * V_{C E}\right)+\left(A_{2} * V_{C E}{ }^{2}\right)+\left(B_{1}{ }^{*} V_{C l}\right)+\left(B_{2} * V_{C l}{ }^{2}\right)+\left(C_{1} * T_{R C l}\right)+\left(C_{2}{ }^{*} T_{R C l}{ }^{2}\right)+\left(D_{1} * \frac{T_{R C E}}{T_{R C l}}\right)+\left(D_{2} * V_{C l}{ }^{*} T_{R C l}\right)$

$\dot{Q}_{\text {condenser }}=A_{0}+\left(A_{1} * V_{C E}\right)+\left(A_{2} * V_{C E}{ }^{2}\right)+\left(B_{1} * V_{C I}\right)+\left(B_{2} * V_{C I}{ }^{2}\right)+\left(C_{1} * T_{R C E}\right)+\left(C_{2}{ }^{*} T_{R C E}{ }^{2}\right)+\left(D_{1} * \frac{T_{R C E}}{T_{R C l}}\right)+\left(D_{2} * V_{C I}{ }^{*} T_{R C I}\right)$

$\dot{P}_{\mathrm{HP}}=\mathrm{A}_{0}+\left(\mathrm{A}_{1}{ }^{*} \mathrm{~V}_{\mathrm{CI}}\right)+\left(\mathrm{A}_{2}{ }^{*} \mathrm{~V}_{\mathrm{Cl}}{ }^{2}\right)+\left(\mathrm{B}_{1}{ }^{*} \mathrm{~V}_{\mathrm{CE}}\right)+\left(\mathrm{B}_{2}{ }^{*} \mathrm{~V}_{\mathrm{CE}}{ }^{2}\right)+\left(\mathrm{C}_{1}{ }^{*} T_{\mathrm{RCI}}\right)+\left(\mathrm{C}_{2}{ }^{*} T_{\mathrm{RCI}}{ }^{2}\right)+\left(\mathrm{D}_{1}{ }^{*} \mathrm{~T}_{\mathrm{RCE}}\right)+\left(\mathrm{D}_{2}{ }^{*} \mathrm{~T}_{\mathrm{RCE}}{ }^{2}\right)+\left(\mathrm{E}_{1}{ }^{*} \mathrm{~T}_{\mathrm{RCI}}{ }^{*} \mathrm{~V}_{\mathrm{CE}}\right)$

Heating Mode Correlations

$\dot{Q}_{\text {evaporator }}=A_{0}+\left(A_{1} * V_{C E}\right)+\left(A_{2} * V_{C E}^{2}\right)+\left(B_{1} * V_{C I}\right)+\left(B_{2} * V_{C I}^{2}\right)+\left(C_{1} * T_{R C E}\right)+\left(C_{2} * T_{R C E}{ }^{2}\right)+\left(D_{1} * \frac{T_{R C l}}{T_{R C E}}\right.$

$\dot{Q}_{\text {condenser }}=A_{0}+\left(A_{1} * V_{C E}\right)+\left(A_{2} * V_{C E}{ }^{2}\right)+\left(B_{1} * V_{C I}\right)+\left(B_{2} * V_{C I}{ }^{2}\right)+\left(C_{1} * T_{R C I}\right)+\left(C_{2} * T_{R C I}{ }^{2}\right)+\left(D_{1} * \frac{T_{R C l}}{T_{R C E}}\right)$

$\dot{P}_{\mathrm{HP}}=\mathrm{A}_{0}+\left(\mathrm{A}_{1} * \mathrm{~V}_{\mathrm{CE}}\right)+\left(\mathrm{A}_{2}{ }^{*} \mathrm{~V}_{\mathrm{CE}}{ }^{2}\right)+\left(\mathrm{B}_{1}{ }^{*} \mathrm{~V}_{\mathrm{CI}}\right)+\left(\mathrm{B}_{2}{ }^{*} \mathrm{~V}_{\mathrm{CI}}{ }^{2}\right)+\left(\mathrm{C}_{1}{ }^{*} \mathrm{~T}_{\mathrm{RCE}}\right)+\left(\mathrm{C}_{2}{ }^{*} \mathrm{~T}_{\mathrm{RCE}}{ }^{2}\right)+\left(\mathrm{D}_{1}{ }^{*} T_{\mathrm{RCI}}\right)+\left(\mathrm{D}_{2}{ }^{*} T_{\mathrm{RCI}}{ }^{2}\right)+\left(\mathrm{E}_{1}{ }^{*} \mathrm{~T}_{\mathrm{RCE}}{ }^{*} \mathrm{~V}_{\mathrm{CI}}\right)$

In order to optimise Eqs. (4) to (9), it was considered to be probable that a relationship would exist between heat exchanger capacity, heat exchanger water mass flow rate and water return temperatures. Several linear and quadratic terms for the water mass flow rates of the internal and external circuits $\left(\mathrm{V}_{\mathrm{CI}}, \mathrm{V}_{\mathrm{CE}}\right)$ were considered to account for this relationship. In order to include the effect of water return temperature, it was first necessary to distinguish between cooling and heating modes. In cooling mode the evaporator is coupled to the building circuit and the condenser to the ground loop, whereas in heating mode the evaporator is coupled to the ground loop and the condenser to the building. To account for this, linear and quadratic terms for the water return temperature from the building circuit were added to correlate the evaporator capacity in Eqs. (4) and (8). Similar terms were included in Eqs. (5) and (7), in order to determine the condenser capacity based on the water return temperature of the external circuit. As the compressor power input is affected by both the external and internal water return temperatures, both linear and quadratic terms were utilised in Eqs. (6) and (9). Second, the ratio between the water return temperature for the external and internal circuits was incorporated in order to correlate the evaporator and condenser capacities $\left(\mathrm{T}_{\mathrm{RCE}} / \mathrm{T}_{\mathrm{RCI}}\right)$. Taking into account, that in cooling mode, the condensation temperature is influenced by the external circuit water temperature and the evaporation temperature is influenced by the building return water temperature, this term was also coupled to the pressure ratio. Similarly for heating mode, the ratio would correspond to the water return temperature for the internal and external circuit $\left(\mathrm{T}_{\mathrm{RC}} / \mathrm{T}_{\mathrm{RCE}}\right)$. Third, a further cross term $\left(\mathrm{V}_{\mathrm{CI}} * \mathrm{~T}_{\mathrm{RCI}}\right)$ was considered in Eqs. (4) and (5), to account for the effect on evaporator and condenser capacities varying in the internal circuit due to changes in water mass flow rate and the water return temperature. Finally, another cross term was incorporated into the power input correlations (Eqs. (6) and (9)), which accounts for the influence of the water mass flow rate in the condenser $\left(\mathrm{V}_{\mathrm{CI}}\right.$ for heating mode and $\mathrm{V}_{\mathrm{CE}}$ for cooling mode) and the 
water return temperature in the evaporator $\left(\mathrm{T}_{\mathrm{RCE}}\right.$ for heating mode and $\mathrm{T}_{\mathrm{RCI}}$ for cooling mode).

A comparison between experimental results and predictions was carried out for a typical day, both for cooling and heating. For cooling mode, Fig. 3 to 5 show the comparison between experimental results and correlated predictions using Eqs. (4) to (6) for a 10 hour period. As can be observed on the right hand axes of Fig. 3 to 5, experimental measurements for cooling capacity and power input are predicted by the polynomial correlations with a maximum mean deviation better than $5 \%$ for cooling capacity and $2.4 \%$ for power input. However, a maximum mean deviation of approximately $13.8 \%$ was observed for heating mode. The maximum deviations were observed at start-up, most likely due to transient conditions. These deviations were corrected in the model.

Fig. 3. Evaporator capacity (Cooling): Correlated data fit and experimental data

Fig. 4. Condenser capacity (Cooling): Correlated data fit and experimental data.

Fig. 5. Compressor power (Cooling): Correlated data fit and experimental data.

\subsection{GSHP System Simulation Model}

A system mathematical model of the overall GSHP unit, as outlined in Fig. 1(a), was developed using Engineering Equation Solver [17]. This model incorporated each of the system components including: fan coils, circulation pumps, hydronic pipe network, storage tank, building conditioned space, as well as the heat pump performance maps as described by Eqs. (4) to (9). Each of these sub-systems is discussed further in the following sections.

Fan Coils: Experimental characterisation of the fan coil units was carried out to allow performance maps to be established for the fan coil UA value (dependent variable) as a function of the air volumetric flow rate and the water mass flow rate (independent variables). The internal circulation pump frequency was varied from 20 to $60 \mathrm{~Hz}$ (in $10 \mathrm{~Hz}$ increments), in conjunction with the three fan speed settings (V1, V2 and V3), and the experimental UA value noted. For each fan speed, the value of the air flow rate was based on data supplied from the manufacturer $\left(290 \mathrm{~m}^{3} / \mathrm{h}, 440 \mathrm{~m}^{3} / \mathrm{h}\right.$, $590 \mathrm{~m}^{3} / \mathrm{h}$ ). Fig. 6 shows the correlated UA values as a function of water mass flow rate for one fan speed (V1), and the associated UA correlation. Similar correlations were established for the other two fans speeds (V2 and V3).

Fig. 6. Fan coil UA correlation (Fan speed V1).

Circulation Pumps (Internal and External): The water flow rate for each circuit is dependent on the pump and system characteristics. Calculation of the mass flow rates for each pump was based on fitting empirical polynomial correlations to the experimental data. Fig. 7 shows the relationship between the measured water mass flow rate (dependent variable) and the internal pump frequency (independent variable). A similar approach was used to map the performance of the external pump. The pump inverter efficiency was experimentally characterised and the following correlation was determined for inverter efficiency as a function of pump frequency:

Inverter efficiency $=\left[-0.0261\left(\mathrm{~F}_{\mathrm{REQ}}\right)^{2}+2.335\left(\mathrm{~F}_{\mathrm{REQ}}\right)+43.765\right] / 100$ 
Fig. 7. Circulation pump correlation (Internal Pump)

Hydronic Pipe Network: The internal hydronic circuit connects the heat pump refrigeration circuit with the building fan coil units. The network is modelled using the Lax-Wendroff model for 2D conduction transport [21]. The flow in the pipes is governed by the transport equation which can be written as follows:

$$
\frac{\partial T_{\text {water }}}{\partial t}=v_{\text {water }} \cdot \frac{\partial T_{\text {water }}}{\partial x}+\frac{P \cdot U}{\rho_{\text {water }} \cdot A \cdot C_{\text {pwater }}} \cdot\left(T_{\text {water }}-T_{\infty}\right)
$$

As the network is assumed to have negligible losses to the ambient, Eq. (11) can be simplified as follows:

$$
\frac{\partial \mathrm{T}_{\text {water }}}{\partial \mathrm{t}}=\mathrm{v}_{\text {water }} \cdot \frac{\partial \mathrm{T}_{\text {water }}}{\partial \mathrm{x}}
$$

Eq. (12) is a hyperbolic partial differential equation and it is solved using the Lax \& Wendroff explicit discretisation approximation. This is governed by the CourantFriedrichs-Lewy (CFL) condition, which is subject to the following constraint:

$$
\Delta \mathrm{t} \leq \frac{\Delta \mathrm{x}}{\mathrm{v}_{\text {water }}}
$$

The CFL condition implies that for a given velocity of the water circulating in the pipes, the time step is controlled by the distance between the two consecutive nodes considered. The discretised version of Eq. (12) is re-written as follows:

$$
\frac{d T_{\text {water }}}{d t_{i}}=\frac{-v_{\text {water }}}{2 \cdot d x}\left[T_{\text {water }_{i+1}}-T_{\text {water }_{i-1}}-\left(\frac{T_{\text {water }_{i+1}}-2 \cdot T_{\text {water }_{i}}+T_{\text {water }_{i+1}}}{d x}\right) \cdot v_{\text {water }} \cdot d t\right]
$$

Solving (14) gives an explicit solution for each network node N, as follows:

$$
\mathrm{T}_{\text {water }_{\mathrm{i}}}=\mathrm{T}_{\text {water }_{\text {initial, } \mathrm{i}}}+\int_{0}^{\mathrm{t} \text {,final }}\left(\frac{\mathrm{dT} \mathrm{w}_{\text {water }}}{\mathrm{dt} \mathrm{t}_{\mathrm{i}}}\right) \mathrm{dt} \text { for } \mathrm{i}=2 \text { to } \mathrm{N}-1
$$

Storage Tank: A storage tank is located at the outlet of the internal circulation pump and provides thermal inertia within the system. It was modelled as follows:

$$
M_{\text {water }} \cdot C p_{\text {water }} \cdot \frac{d T_{\text {water }}}{d t}=\dot{m}_{I C P} \cdot C_{\text {pwater }} \cdot\left(T_{\text {out }, H P}-T_{\text {water }}\right)+U A \mid \cdot\left(T_{\text {water }}-T_{\infty}\right)
$$

Assuming negligible heat losses from the tank, Eq. (16) can be simplified to:

$$
\frac{\mathrm{dT}_{\text {water }}}{\mathrm{dt}}=\frac{\dot{\mathrm{m}}_{\mathrm{ICP}} \cdot\left(\mathrm{T}_{\text {out }, H P}-\mathrm{T}_{\text {water }}\right)}{\mathrm{M}_{\text {water }}}
$$

Building Conditioned Space: Each of the spaces within the building was modelled assuming a constant volume closed system for the space as follows:

$$
\mathrm{M}_{\text {air }} \mathrm{c}_{\text {pair }} \frac{\mathrm{dT}}{\mathrm{dt}}=\dot{\mathrm{Q}}_{\text {FanCoil }}+\dot{\mathrm{Q}}_{\text {load }}
$$

where $\dot{\mathrm{Q}}_{\text {FanCoil }}$ is the heating/cooling capacity associated with the fan coil and is given by: 


$$
\dot{\mathrm{Q}}_{\text {FanCoil }}=\dot{\mathrm{m}}_{\text {air }} \mathrm{c}_{\text {pair }} \varepsilon_{\mathrm{FC}} \cdot\left(\mathrm{T}_{\text {air }}-\mathrm{T}_{\text {in,water }}\right)
$$

and $\dot{\mathrm{Q}}_{\text {load }}$ is the heating or cooling load associated with the space and is calculated as follows:

$$
\dot{\mathrm{Q}}_{\mathrm{load}}=\mathrm{UA} \cdot\left(\mathrm{T}_{\mathrm{amb}}-\mathrm{T}_{\text {air }}\right)+\dot{\mathrm{Q}}_{\text {internalgains }}
$$

where $\dot{Q}_{\text {internalgains }}$ is the thermal load associated with the presence of people, computers and any other internal loads. For this study, an average load of $200 \mathrm{~W}$ was empirically determined for each space and an occupancy level of 50\% was assumed.

The $\mathrm{U}$ values utilised in the model for the building external walls and windows were $0.6 \mathrm{~W} \cdot \mathrm{m}^{-2} \mathrm{~K}^{-1}$ and $5.75 \mathrm{~W} \cdot \mathrm{m}^{-2} \mathrm{~K}^{-1}$ respectively. By considering all thermal loads to include fabric gains, solar gains, internal gains, infiltration and ventilation loads, a peak design load normalised with respect to floor area, with an external design temperature of $35^{\circ} \mathrm{C}$ and internal set-point temperature of $23.5^{\circ} \mathrm{C}$, was determined to be $102 \mathrm{~W} \cdot \mathrm{m}^{-2}$.

\section{Model Validation}

Validation of the system model was undertaken by comparing model predictions and experimental data taken from the UPV GSHP installation. Fig. 8 compares model predictions for space and water temperatures against experimental data for a typical heat pump cycle period. For this data, the following boundary conditions were applicable for the system mathematical model:

- Space set-point temperature $23.5^{\circ} \mathrm{C}$

- Space temperature bandwidth $\pm 0.5^{\circ} \mathrm{C}$

- Building return water set-point temperature $10.4^{\circ} \mathrm{C}$

- Building return water bandwidth $\pm 1.6^{\circ} \mathrm{C}$

- Internal circulation pump frequency $60 \mathrm{~Hz}$

- External circulation pump frequency $50 \mathrm{~Hz}$

- External ambient temperature corresponding to July $29^{\text {th }}, 2009$

Fig. 8 shows the evolution of the inlet and outlet temperatures for the internal circuit and the space temperature for one office in the building. In order to analyse system performance, critical points have been identified (Points 1 to 7) in Fig. 8. The heat pump can be observed to switch off, when the return temperature reaches the lower set-point of $8.8^{\circ} \mathrm{C}$ (Point 1). A delay of approximately one minute can be observed until equalisation of the supply and return temperatures occurs, which is attributed to the thermal inertia of the evaporator. Once the heat pump has been switched off, the supply temperature increases until point 2 , and the return temperature continues to decrease due continued circulation of the remaining $6^{\circ} \mathrm{C}$ chilled supply water until it reaches point 3 . At point 3 , as the heat pump is switched off, the building cooling load results in a gradual increase in the building return temperature. A thermal time-lag, attributed to the hydronic loop inertia, can be observed between points 2 and 3. At point 4 , as the return temperature reaches its upper set-point of $12^{\circ} \mathrm{C}$, the heat pump switches on and the supply temperature drops until it reaches a quasi-steady temperature of $8.8^{\circ} \mathrm{C}$ at point 5 . The return temperature continues to increase due to space cooling load, until the chilled water once more reaches the fan coils, with an associated time lag of approximately 3 minutes evident between points 4 and 6 . This delay is produced by the thermal inertia of the internal hydronic circuit. Once chilled 
water reaches the fan coils, as the building load is less than heat pump capacity, the return water temperature decreases until it reaches $8.8^{\circ} \mathrm{C}$ at point 7 , where the heat pump switches off and cycle recommences.

Space temperature is also shown in Fig. 8 for one of the building offices. A space temperature set-point of $23.5^{\circ} \mathrm{C}$ was used, which is selectable by the user. Space air temperature, which varies according to the fan coil operation, is governed by a 3-way valve, that either circulates the chilled water through the fan coil or past it by means of the valve bypass action. This valve is controlled by the room thermostat, such that if the space temperature is $24^{\circ} \mathrm{C}$, the 3 -way valve circulates the chilled water through the fan coil, such that the space temperature decreases until it reaches $23^{\circ} \mathrm{C}$. At this point, the chilled water will be diverted to the return circuit via the bypass. During the phase, as fan cooling action ceases, the space temperature increases until it reaches to $24^{\circ} \mathrm{C}$ and the cycle starts again.

Fig. 8. Comparison of system model predictions with building experimental data (July 29, 2009)

Fig. 9 shows a set of simulation results for a 24 hour period, subject to a peak external ambient boundary condition of $35^{\circ} \mathrm{C}$ and an internal set-point temperature of $23^{\circ} \mathrm{C}$. After an initial pull down period, quasi-steady behaviour is observed to occur, with an increase in heat pump ON cycle time, observable between 12:00 and 18:00 hours, reflecting increased cooling demand during the afternoon period.

Fig. 9. Daily temperature profile - system mathematical model

Fig. 10 shows the experimental measurements obtained for the $29^{\text {th }}$ of July, 2009. It can be observed that the simulation results for the return and supply water temperatures are very similar to experimental data. The space temperature, however, presents a different evolution. This is attributed to simplifications associated with calculating the thermal load for each building space as discussed in Section 4.3. Moreover, fan speed settings for each fan coil unit have been assumed at a single fixed speed for all spaces.

Fig. 10. Daily temperature profile - system experimental measurements

In order to characterise overall performance, a number of additional parameters were calculated as follows. The ON/OFF time operation of the heat pump was determined, and is presented as a percentage for the heat pump in either ON and OFF mode, with reference to a 24 hour period (1440 minutes). The seasonal performance factors of the heat pump and the system were also calculated based on a daily analysis, as per Eqs. (21) and (22).

$$
\mathrm{SPF}_{\mathrm{HP}}=\frac{\int_{0}^{\mathrm{t}} \dot{\mathrm{Q}}_{\mathrm{c}} \cdot \mathrm{dt}}{\int_{0}^{\mathrm{t}} \dot{\mathrm{P}}_{\mathrm{HP}} \cdot \mathrm{dt}}
$$




$$
\mathrm{SPF}_{\text {SYSTEM }}=\frac{\int_{0}^{\mathrm{t}} \mathrm{Q}_{\mathrm{c}} \cdot \mathrm{dt}}{\int_{0}^{\mathrm{t}} \dot{\mathrm{P}}_{\text {SYSTEM }} \cdot \mathrm{dt}}
$$

Table 1 shows the results as determined for the experimental measurements and simulation predictions. It can be observed that the model predictions are very close to experimental data with a maximum absolute deviation of $3.26 \%$.

Table 1 System performance parameters: experimental versus simulation results

\section{Sensitivity Study}

The sensitivity of GSHP performance subject to control of set-point temperature of the fan coil water return temperature and the space air temperature are examined in this section. In addition the role of bandwidth settings for the fan coil water return temperature and space air temperature are also considered. The sensitivity studies presented here are only for cooling mode, additional data is available for heating mode, but is not considered in this paper.

\subsection{Sensitivity Study Boundary Conditions}

For cooling mode, the following reference boundary conditions were applicable:

- Space set-point temperature $23^{\circ} \mathrm{C}$

- Space temperature bandwidth $\pm 1^{\circ} \mathrm{C}$

- Fan coil water return temperature $12^{\circ} \mathrm{C}$

- Fan coil water return temperature bandwidth $\pm 1^{\circ} \mathrm{C}$

- Internal circulation pump frequency $60 \mathrm{~Hz}$

- External circulation pump frequency $50 \mathrm{~Hz}$

- External ambient temperature corresponding to the July $29^{\text {th }}, 2009$

\subsection{Set-point Control of Water Return Temperature}

The effect of set-point control of building water return temperature was examined using the system model. Three water return temperatures, $10^{\circ} \mathrm{C}, 12^{\circ} \mathrm{C}$ and $14^{\circ} \mathrm{C}$ were considered. All other system variables were constrained at the boundary conditions described in Section 6.1. Fig. 11 illustrates the effect of different water return setpoint temperatures on return temperature evolution for a typical 200 minute operational period of the system. It can be observed that, as the building water return set-point temperature is increased from $10^{\circ} \mathrm{C}$ to $14^{\circ} \mathrm{C}$, the heat pump compressor $\mathrm{ON}$ time decreases due to the increased cooling capacity associated with the underlying refrigeration cycle. Analysis shows that capacity increases by approximately $3.6 \%$ per degree increase of the building return water temperature. Fig. 12 summarises the heat pump compressor cycle data. As the building water return temperature increases, the compressor ON cycle time percentage is observed to decrease from $42.3 \%$ to $37.1 \%$, which is equivalent to 610 minutes and 535 minutes respectively. Therefore the main effect of increasing building water return temperature, is that resulting from increased refrigeration capacity, an increased fan coil capacity is available, resulting in increased space cooling capabilities, leading to a shorter heat pump ON period.

Fig. 11. Building water return temperature evolution 
Fig. 12. Compressor cycle period data versus building water return temperatures

Fig. 13 shows the daily system power consumption, associated with the data in Fig. 11. Compressor power consumption is observed to decrease from $30.19 \mathrm{kWh}$ to 27.07 $\mathrm{kWh}$, as the building return temperature increases, as does the total system consumption which decreases from $59.38 \mathrm{kWh}$ to $57.34 \mathrm{kWh}$. Moreover, the daily SPF for the heat pump increases from 4.75 to 5.24. On the other hand, the daily SPF of the system remains almost constant, as the decrease in total power consumption is offset by the decrease in thermal energy supplied to the system. Nevertheless, it is important to point out that variations in the return water temperature would have greater effect on the SPF of the system for milder ambient conditions, which may present a lower building cooling demand and a thus lower fan coil power consumption.

Fig. 13. Energy consumption and daily SPF versus building water return temperatures

\subsection{Set-point Control of Space Temperature}

Space temperature is controlled by an individual thermostat located in each room. Three separate space set-point temperatures $\left(21^{\circ} \mathrm{C}, 23^{\circ} \mathrm{C}\right.$ and $\left.25^{\circ} \mathrm{C}\right)$ were analysed and the simulation predictions are shown in Fig. 14. All other boundary conditions were maintained as outlined in Section 6.1. Space temperature set-point is seen to have a significant influence on heat pump cyclic behaviour. An increase in space set-point temperature will result in a decrease in the building heat gains. At higher space temperatures, due to the higher mean temperature difference between the space and the coil mean water temperature, a larger space to fan coil heat transfer load is possible, and thus the water return temperature is observed to cool faster during the heat pump ON periods, given that the heat pump capacity remains constrained and is therefore unchanged. Thus for higher space set-point temperatures, the building water return temperature reaches the lower set-point temperature more quickly, resulting in a more frequent heat pump cycling associated with higher space temperature setpoints.

Fig. 14. Set-point control of space temperature

Fig. 15 summarises the heat pump ON/OFF cycle time for each of the space set-point temperatures, whereas Fig. 16 gives daily power consumption and SPF of the heat pump and the system. Total system power consumption decreases as $\mathrm{T}_{\text {space }}$ is increased, which is due to the decreased compressor ON time and its associated power requirement. It can be observed in Fig. 16, that the daily SPF of the heat pump remains practically constant, whereas $\mathrm{SPF}$ of the system decreases as the space setpoint temperature increases from $21^{\circ} \mathrm{C}$ to $25^{\circ} \mathrm{C}$. This is because the building cooling load demand decreases at the same rate as heat pump energy consumption but at a greater rate than the total energy consumption.

Fig. 15. Compressor cycle data

Fig. 16. Energy consumption and daily SPF as a function of space set-point temperature 


\subsection{Building Water Return Bandwidth}

Bandwidth control for building water return temperature was examined for bandwidths of $\pm 0.5^{\circ} \mathrm{C}, \pm 1^{\circ} \mathrm{C}, \pm 1.5^{\circ} \mathrm{C}, \pm 2^{\circ} \mathrm{C}$ and the simulation predictions are shown in Fig. 17. All other variables were maintained at the reference boundary conditions as outlined in Section 6.1. Reference to Table 2 shows that changes in return water bandwidth had a negligible effect on system performance characteristics. The ON time operation of the heat pump can be observed to be not significantly affected by the return temperature bandwidth, so the heat pump energy consumption remains practically the same. In this case, total consumption would only be affected by the fan coils, but it also appears to be not significantly influenced by changes in water return bandwidth, because total consumption of the system is almost constant. Finally, values for the SPF of the system and the heat pump are affected by less than $0.5 \%$ by return water temperature bandwidth. This is because thermal energy supplied to the building is constant.

Fig. 17. Building return temperature as a function of return water bandwidth

Table 2 System performance parameters as a function of return water bandwidth

\subsection{Building Space Temperature Bandwidth}

The role of space temperature bandwidth control was considered for bandwidths of $\pm 0.5^{\circ} \mathrm{C}, \pm 1^{\circ} \mathrm{C}$ and $\pm 1.5^{\circ} \mathrm{C}$. Simulation results are given in Fig. 18 and system performance is summarised in Table 3. For these results, a building space set-point temperature of $23^{\circ} \mathrm{C}$ was used, along with the other boundary conditions given in Section 6.1 Examining Fig. 18, it can be observed that adjusting of the space temperature bandwidth has a modest effect on heat pump cyclic performance, as well as overall system performance. The $\mathrm{ON}$ time operation of the heat pump stays practically the same; this is why heat pump energy consumption remains constant. In this case, as total consumption is only affected by the fan coils, it also appears to be insignificantly affected by changes in space bandwidth temperature as total consumption is practically constant. Finally, values for the SPF of the system and the heat pump are slightly affected, less than $1 \%$, by space temperature bandwidth.

Fig. 18. Building return temperature for different space temperatures bandwidths

Table 3 System performance parameters as a function of return water bandwidth

\section{Conclusions}

This paper examines for ground source heat pumps, how control of building circuit variables affects overall system performance. Variables analysed included: building hydronic circuit set-point temperature, building circuit hydronic temperature bandwidth, building space set-point temperature and building space temperature bandwidth. Assessment was carried out by means of a system mathematical model which was developed using Engineering Equation Solver.

The dominant factor affecting system power consumption was found to be building space set-point temperature. Space set-point temperature directly affects heat gains to 
the building and by association the cooling load. Under quasi-steady state conditions, as the set-point temperature increased from $21^{\circ} \mathrm{C}$ to $25^{\circ} \mathrm{C}$, the daily system power consumption decreased significantly from $67.54 \mathrm{kWh}$ to $48.23 \mathrm{kWh}$. The daily SPF of the heat pump remained practically constant, whereas the daily SPF of the system was decreased from 2.58 to 2.21. Moreover, as $\mathrm{T}_{\text {space }}$ increases, the rate of heat pump cycling was also noted to decrease as compressor ON time was reduced from $48.85 \%$ to $30.05 \%$.

The effect of varying building return water temperature was found to have less influence than space temperature set-point on system power consumption. As building water set-point was increased from $10^{\circ} \mathrm{C}$ to $14^{\circ} \mathrm{C}$, compressor power consumption decreased from $30.19 \mathrm{kWh}$ to $27.07 \mathrm{kWh}$, while compressor ON time was also observed to decrease from $42.33 \%$ to $37.13 \%$. Moreover, the daily SPF for the heat pump improved from 4.75 to 5.24 and the daily SPF of the system increased slightly from 2.41 to 2.47 . Therefore, it would appear that higher water return temperatures reduces the $\mathrm{ON}$ time operation of the heat pump, and results in an increase of daily heat pump SPF of approximately 5\% per each degree increase of the building water return temperature.

Building water return bandwidth was noted to have almost a negligible effect on system and compressor power consumption and compressor ON time was noted to decrease only marginally with increased temperature bandwidth. Daily SPF values for the system and the heat pump were not significantly affected by water return bandwidth. Space temperature bandwidth was also observed to have a negligible effect on compressor and system performance. Finally, it should be noted that overall system performance will be influenced by other factors including: heat pump design, ground loop design, building hydronic loop design and building efficiency. However the influence of these factors on overall system performance were not explored in the current paper.

\section{Acknowledgements}

This work was supported under the FP7 programme "Advanced ground source heat pump systems for heating and cooling in Mediterranean climates" (GROUND-MED FP7-ENERGY-2007-2-TREN-218895).

\section{References}

[1] L. Gasser, B. Wellig, K. Hilfiker, Exergy analysis for increasing the efficiency of air/water heat pumps, Forschungsprogramm UAW Umgebungswärme, Lucerne University of Applied Sciences and Arts, Engineering \& Architecture, CC Thermal Energy Systems \& Process Engineering, Technikumstrasse 21, CH-6048, 2008.

[2] N. Flach-Malaspina, J. Lebreton, D. Clodic, Performance of a new air-to-water heat pump system with controlled capacity, Int. Refrigeration and Air Conditioning Conference, Purdue, 2004. 
[3] P. Riviere, F. Malaspina, J. Lebreton, A new installation for part load testing of air to water single stage chillers and heat pumps, International Refrigeration and Air Conditioning Conference, Purdue, July 12-15, 2004, 1-8.

[4] C. Aprea, R. Mastrullo , Experimental Evaluation Of Electronic And Thermostatic Expansion Valves Performances Using R22 And R407C, Applied Thermal Engineering vol. 22(2) (2002) 205-218.

[5] B. P. Rasmussen, A. G. Alleyne, Control-Oriented Modeling of Transcritical Vapor Compression Systems. J. Dyn. Sys., Meas., Control. 126(1) (2004) 54.

[6] R.J. Dossat, Principles of Refrigeration, fifth ed., Prentice Hall, 2001, ISBN-13: 978-0130272706.

[7] M. Yaqub, S. M. Zubair, Capacity Control for Refrigeration and Air-Conditioning Systems: A Comparative Stud. J. Energy Resour. Technol. 123 (1) (2001) 92.

[8] Renedo, C.J, et al. (2006), 'Optimum design for reversible water-water heat pumps', Energy and Buildings, 38, 1240-1247.

[9] Liu , X Hong, T. (2010) 'Comparison of energy efficiency between variable refrigerant flow systems and ground source heat pump systems' Energy and Buildings, 42, 584-589.

[10] P. Fahlén, F. Karlsson, Optimizing And Controlling Media Flows In Heat Pump Systems, $8^{\text {th }}$ IEA Heat Pump Conference, Las Vegas, USA, 2005.

[11] F. Karlsson, P . Fahlen, Capacity Controlled Ground Source Heat Pumps in Hydronic Heating Systems, Int. Journal of Refrigeration 30(2) (2007) 221-229.

[12] L. Zhao, L. L. Zhaob, Q. Zhang, G. L. Ding, Theoretical and basic experimental analysis on load adjustment of geothermal heat pump systems, Energy Conversion and Management, 44 (1) (2003) 1-9.

[13] Chen, Y. (2000), 'Real-time predictive supervisory operation of building thermal systems with thermal mass', Energy and Buildings, 33, 141-150.

[14] Guo, W, Nutter, D. W. (2010), 'Setback and setup temperature analysis for a classic double-corridor classroom building', Energy and Buildings, 42, 189-197.

[15] Z. Yang, , G. K. M. Pedersen, L. F. S. Larsen, Modeling and Control of Indoor Climate Using a Heat Pump Based Floor Heating System, 33rd Annual Conference of the IEEE Industrial Electronics Society (IECON), Taipei, Taiwan Nov. 5-8, 2007.

[16] J. F. Urchueguía, M. Zacarés, J. M. Corberán, A. Montero, J. Martos , H. Witte, Comparison between the energy performance of a ground coupled water to water heat pump system and an air to water heat pump system for heating and cooling in typical conditions of the European Mediterranean coast, Energy Conversion and Management 49 (2008) 2917-2923. 
[17] Engineering Equation Solver, F-Chart Software, The University of Wisconsin, Madison, 2009.

[18] J. M. Corberán, J. Gonzálvez-Macia, IMST-ART, a computer code to assist the design of refrigeration and air conditioning equipment, www.imst-art.com, IMST, Universidad Politécnica de Valencia, Spain, 2009.

[19] J. M. Corberan, C. Radulescu, J. G. Macia, Performance Characterisation Of A Reversible Water To Water Heat Pump, $9^{\text {th }}$ International IEA Heat Pump Conference, Zürich, Switzerland, 20-22 May 2008.

[20] J. Gonzálvez-Maciá, F. Vera-García, J. R. García-Cascales, J. M. CorberánSalvador, C. Radulescu, (in Spanish) Estudio experimental de la influencia del flujo másico de agua en las prestaciones de una bomba de calor de compresión de propano, Análisis detallado mediante modelado con el programa de cálculo IMST-ART, Congresso Iberico e II Congresso Iberoamericano, Ciencias E Tecnicas de Frio, Porto, Portugal, 2007.

[21] P. D. Lax, B. Wendroff, System of Conservation Laws, Comm. Pure \& Applied Mathematics 13, 1960, pp. 217-237. 


\begin{tabular}{|l|l|l|l|}
\hline $\begin{array}{l}\text { System } \\
\text { Performance Parameters }\end{array}$ & $\begin{array}{l}\text { Simulation } \\
\text { Results }\end{array}$ & $\begin{array}{l}\text { Experimental } \\
\text { Results }\end{array}$ & $\begin{array}{l}\text { Abs } \\
\text { Deviation } \\
(\%)\end{array}$ \\
\hline HP ON (\%) & 41.08 & 41.29 & 0.5 \\
HP OFF (\%) & 58.92 & 58.71 & 0.35 \\
Energy Consumption - HP (kWh) & 29.43 & 29.95 & 1.74 \\
Energy Consumption - System (kWh) & 58.54 & 56.69 & 3.26 \\
Heat Pump Daily SPF (Eqn. 21) & 4.78 & 4.64 & 3.04 \\
System Daily SPF (Eqn. 22) & 2.40 & 2.45 & 1.90 \\
\hline
\end{tabular}

Table 1 System performance parameters: experimental versus simulation results 


\begin{tabular}{|l|l|l|l|l|}
\hline Building Water Return Bandwidth & $\mathbf{\pm 0 . 5 C}$ & $\mathbf{\pm 1 C}$ & $\mathbf{\pm 1 . 5 C}$ & $\mathbf{\mathbf { 2 C }}$ \\
\hline HP ON (\%) & 40.04 & 39.97 & 39.90 & 40.39 \\
HP OFF (\%) & 59.96 & 60.03 & 60.10 & 59.61 \\
Energy Consumption - HP (kWh) & 28.68 & 28.72 & 28.65 & 28.65 \\
Energy Consumption - System (kWh) & 58.35 & 58.40 & 58.32 & 58.32 \\
Daily SPF of the HP & 4.99 & 4.99 & 5.01 & 4.95 \\
Daily SPF of the system & 2.45 & 2.45 & 2.46 & 2.44 \\
\hline
\end{tabular}

Table 2 System performance parameters as a function of return water bandwidth 


\begin{tabular}{|l|l|l|l|}
\hline $\mathbf{T}_{\text {space }}$ Bandwidth & $\mathbf{\pm 0 . 5}$ & $\mathbf{\pm 1 . 0}$ & $\mathbf{\pm 1 . 5}$ \\
\hline Compressor On (\%) & 39.49 & 39.97 & 40.74 \\
Compressor Off (\%) & 60.51 & 60.03 & 59.26 \\
Energy Consumption - HP (kWh) & 28.40 & 28.72 & 29.15 \\
Energy Consumption - System (kWh) & 57.88 & 58.40 & 59.09 \\
Daily SPF of the HP & 4.98 & 4.99 & 5.01 \\
Daily SPF of the system & 2.44 & 2.45 & 2.47 \\
\hline
\end{tabular}

Table 3 System performance parameters as a function of return water bandwidth 


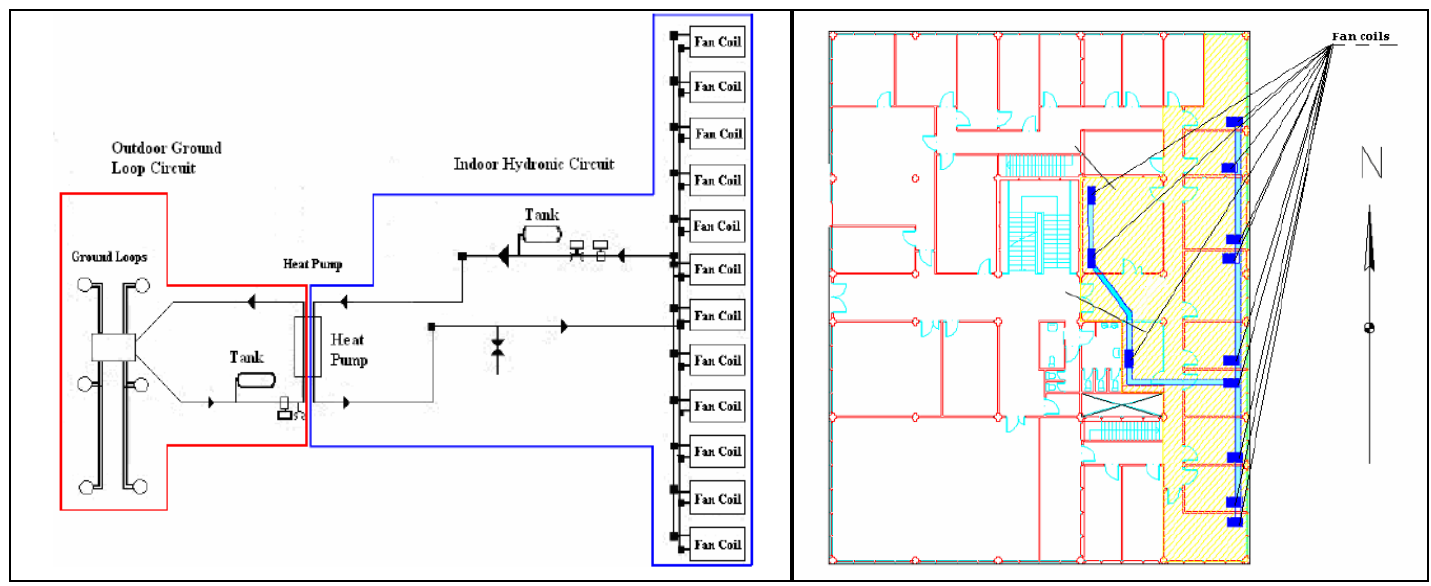

Fig. 1. GSHP system (a) GSHP system schematic (b) Building plan 

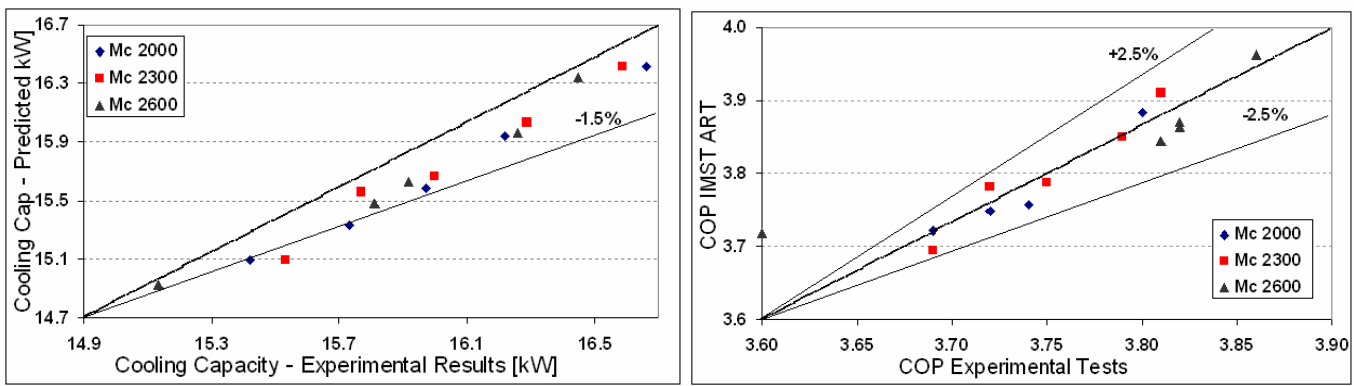

Fig. 2. Validation of IMST-ART heat pump model for different evaporator and condenser flow rates [18]. (Note: $\mathrm{Mc}=$ Condenser water mass flow rate $\mathrm{kg} \cdot \mathrm{hr}^{-1}$ ) 


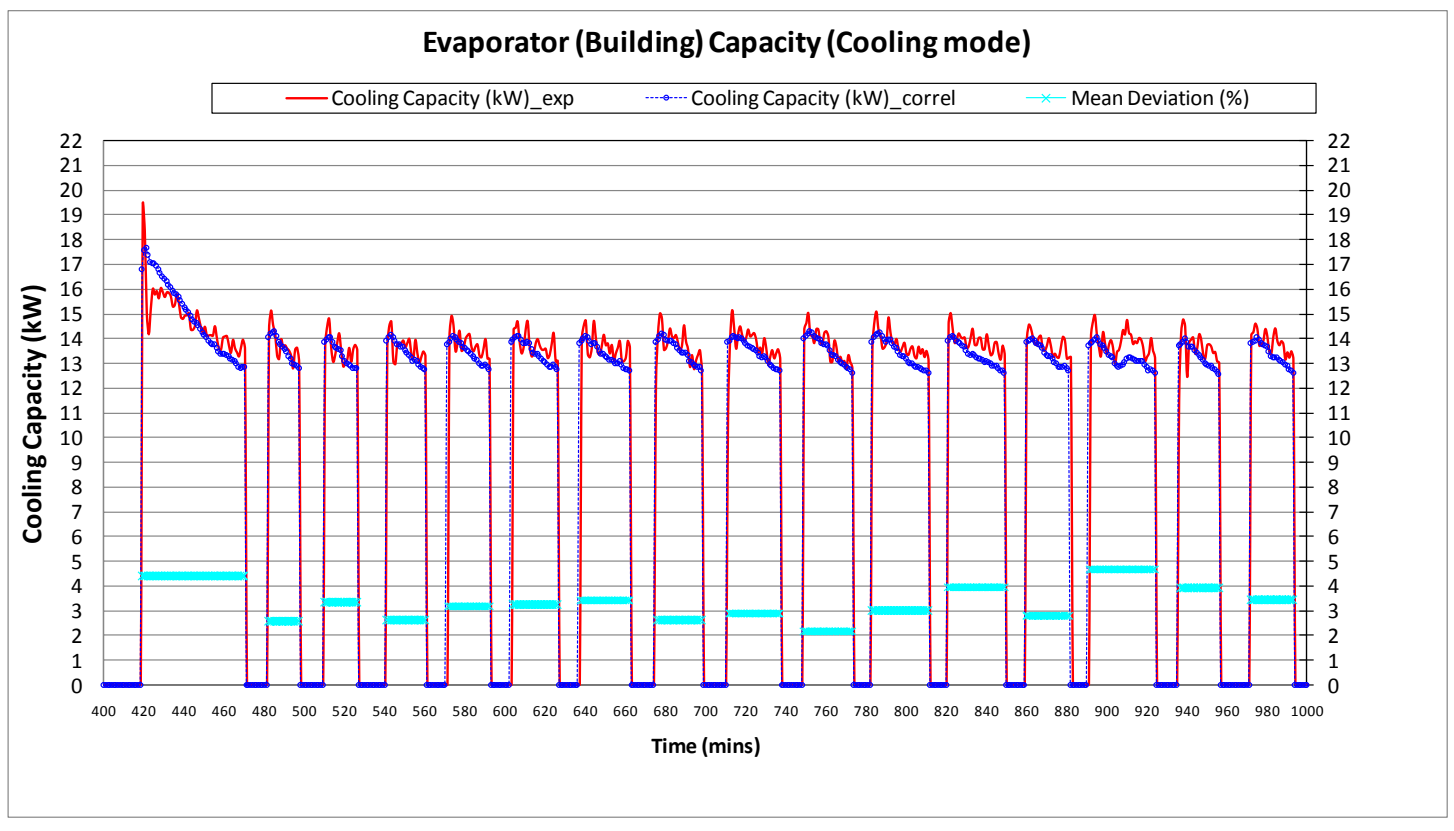

Fig. 3. Evaporator capacity (Cooling): Correlated data fit and experimental data 


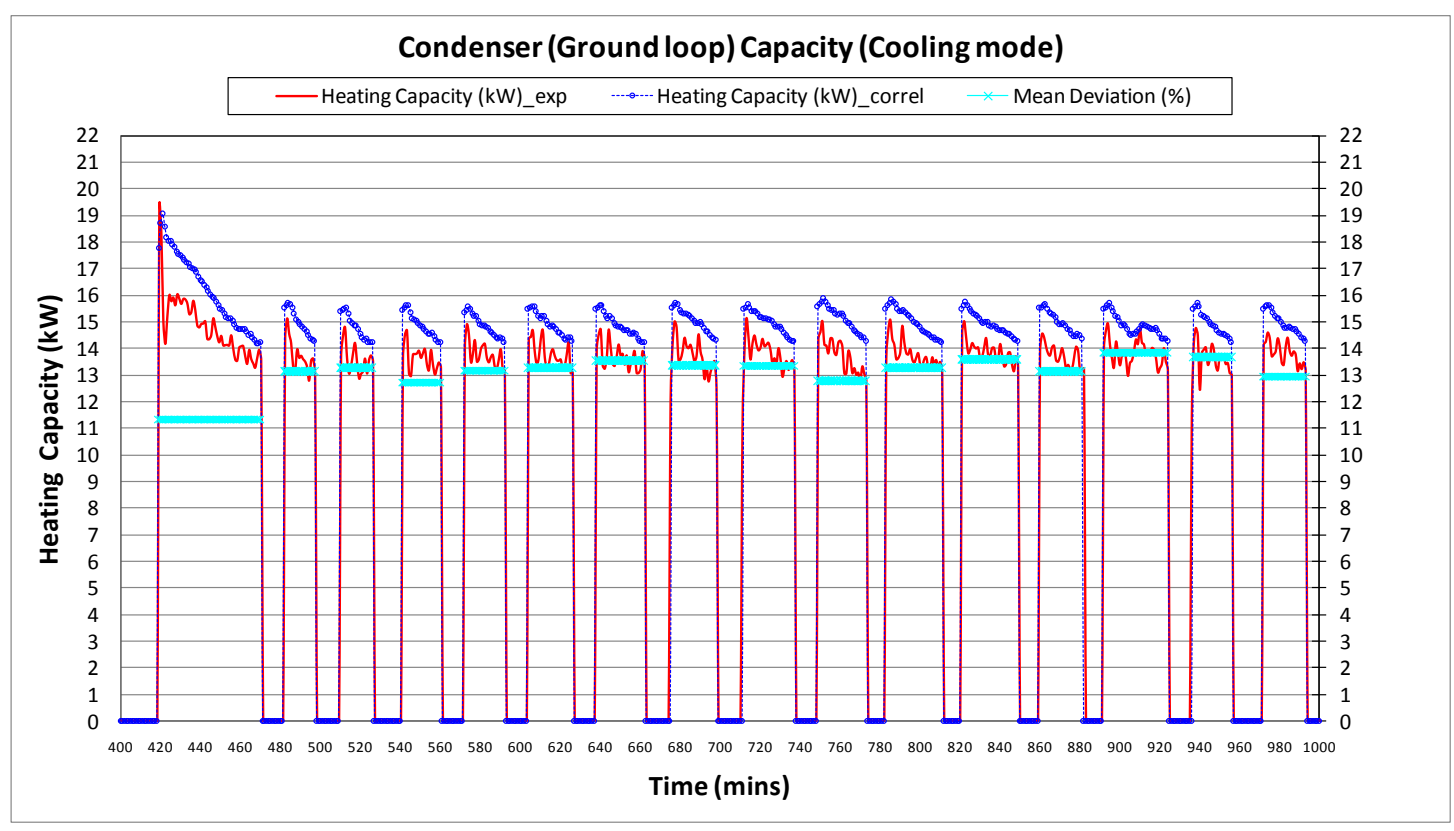

Fig. 4. Condenser capacity (Cooling): Correlated data fit and experimental data. 


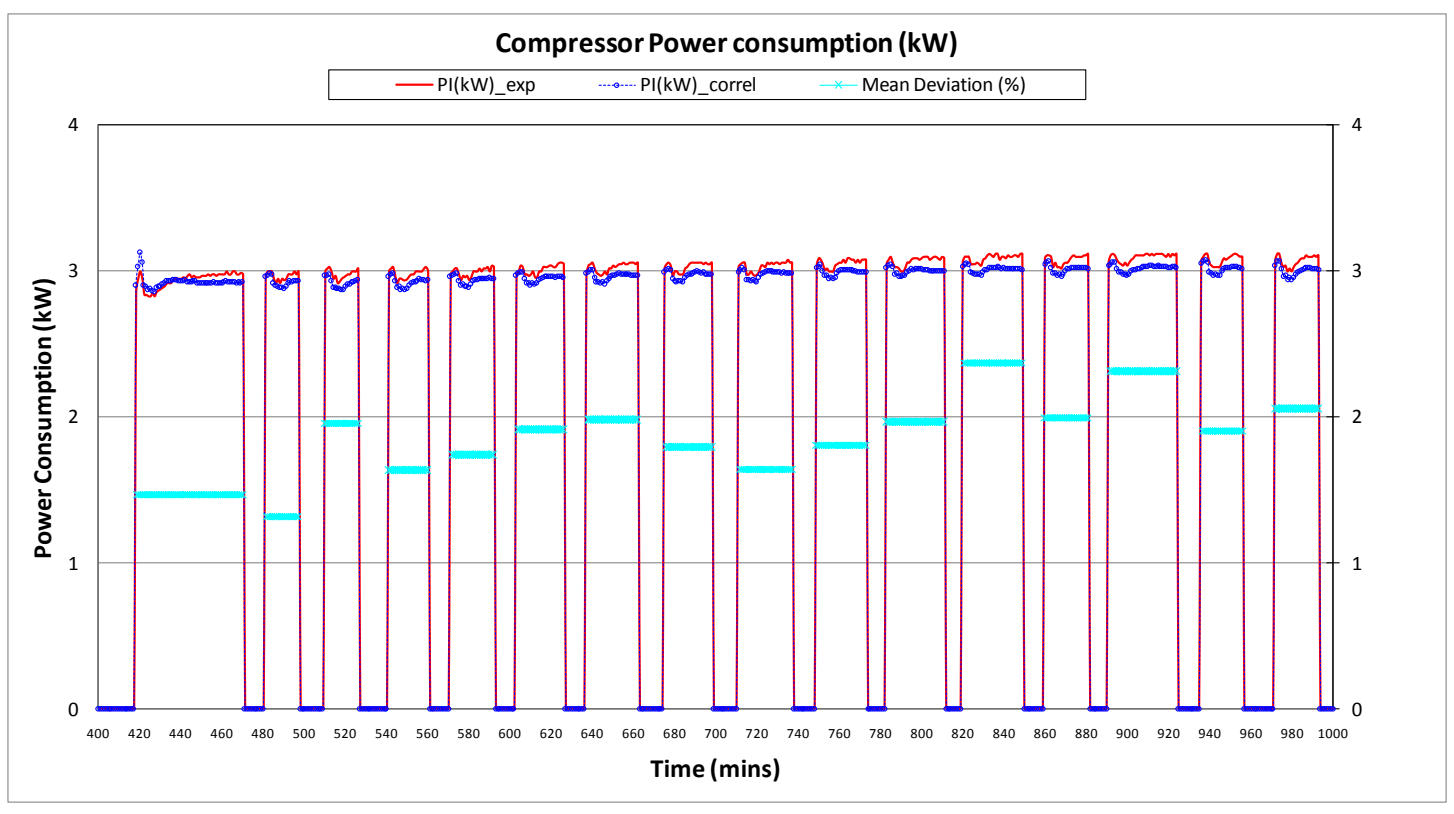

Fig. 5. Compressor power (Cooling): Correlated data fit and experimental data. 


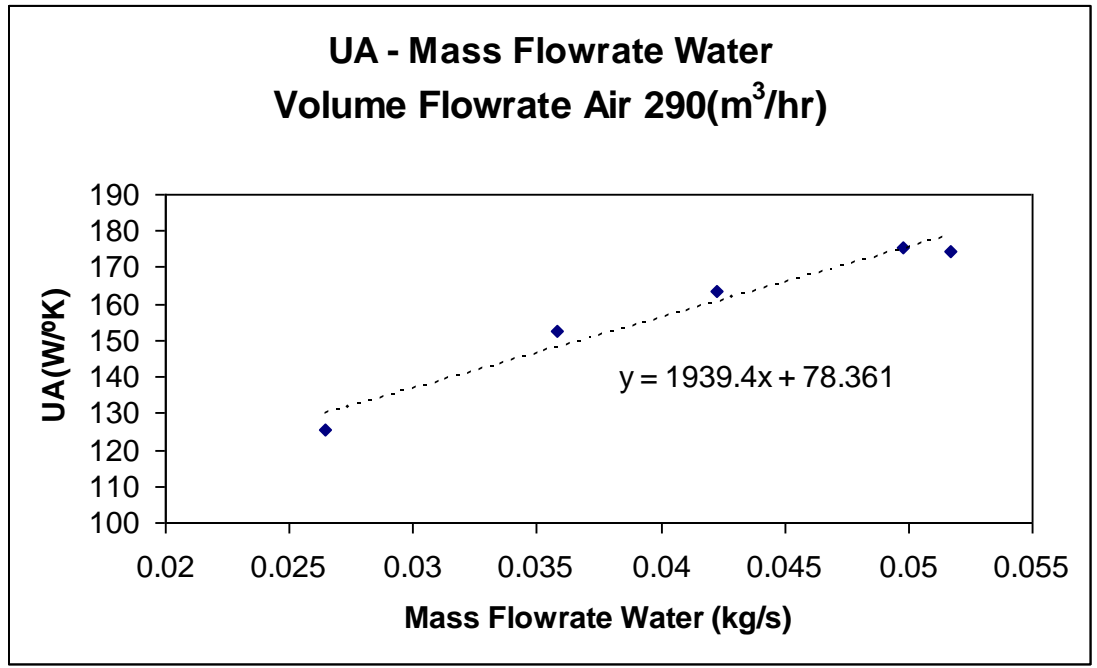

Fig. 6. Fan coil UA correlation (Fan speed V1). 


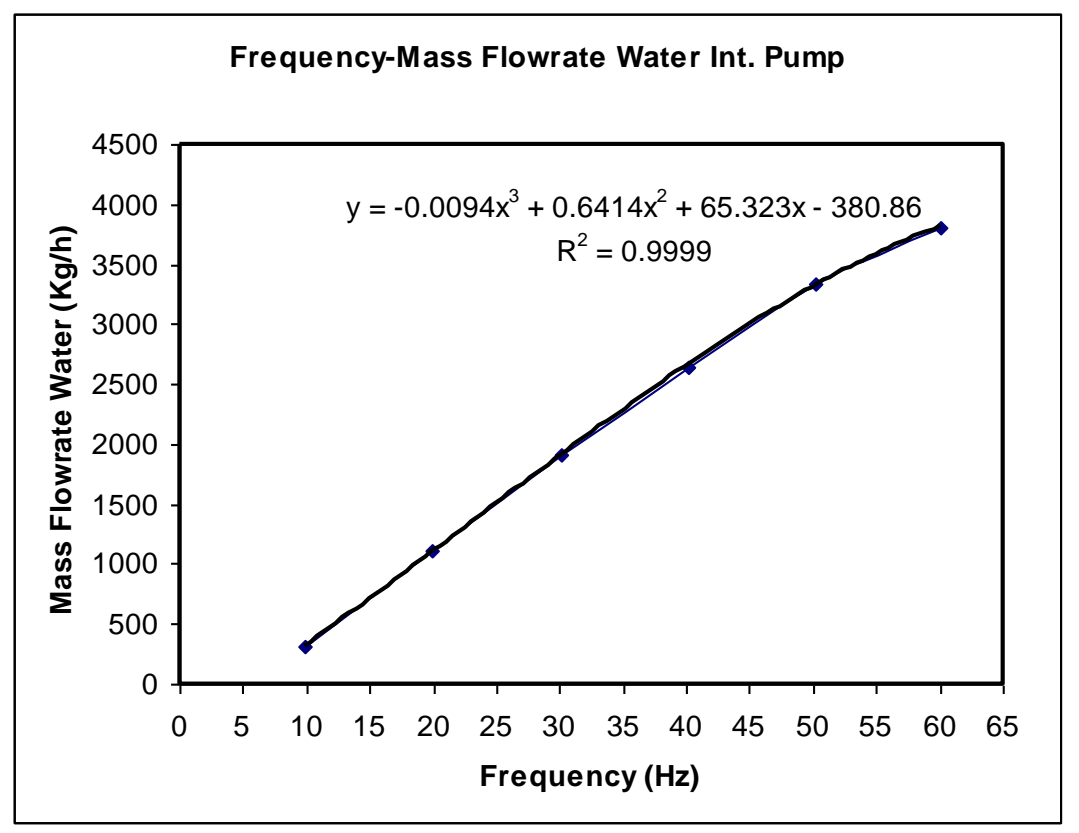

Fig. 7. Circulation pump correlation (Internal Pump) 


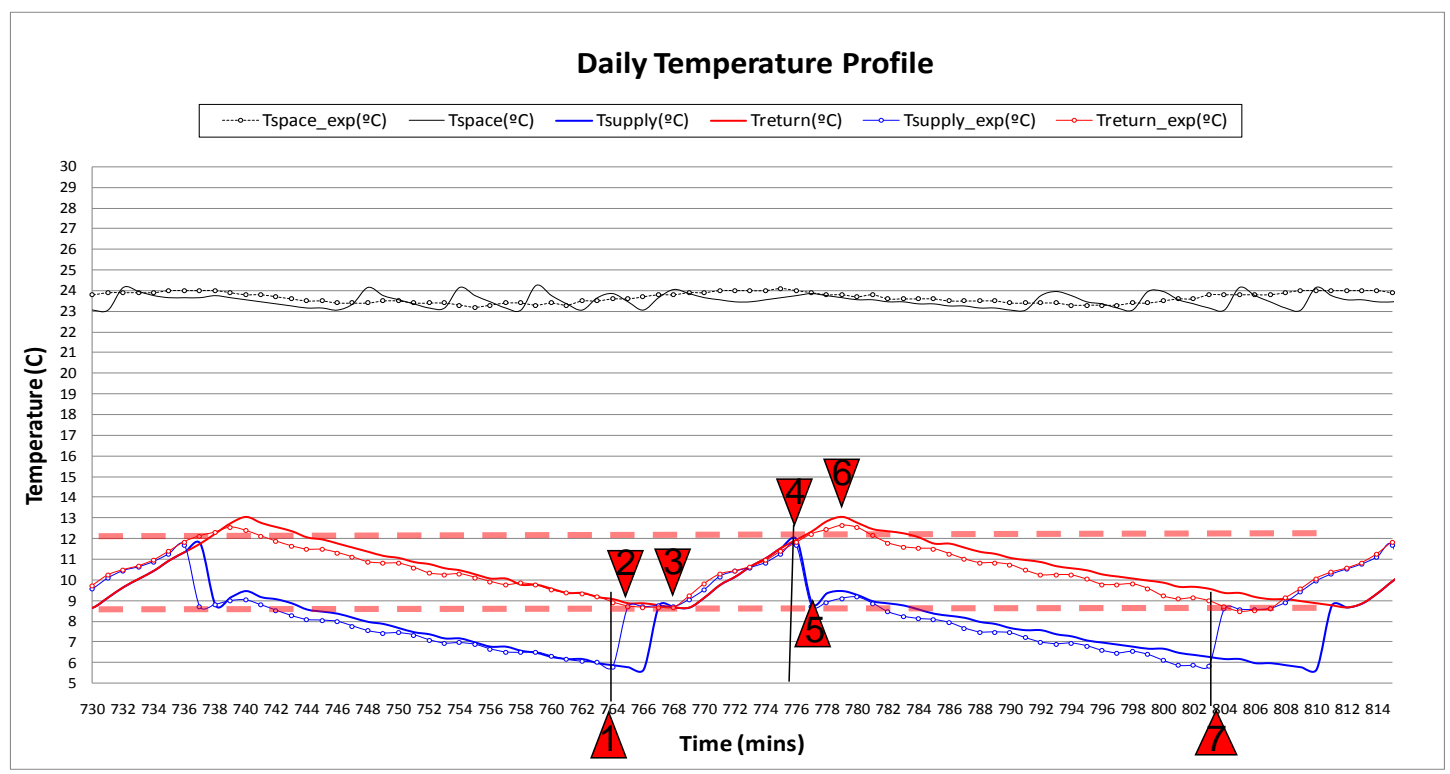

Fig. 8. Comparison of system model predictions with building experimental data (July 29, 2009) 


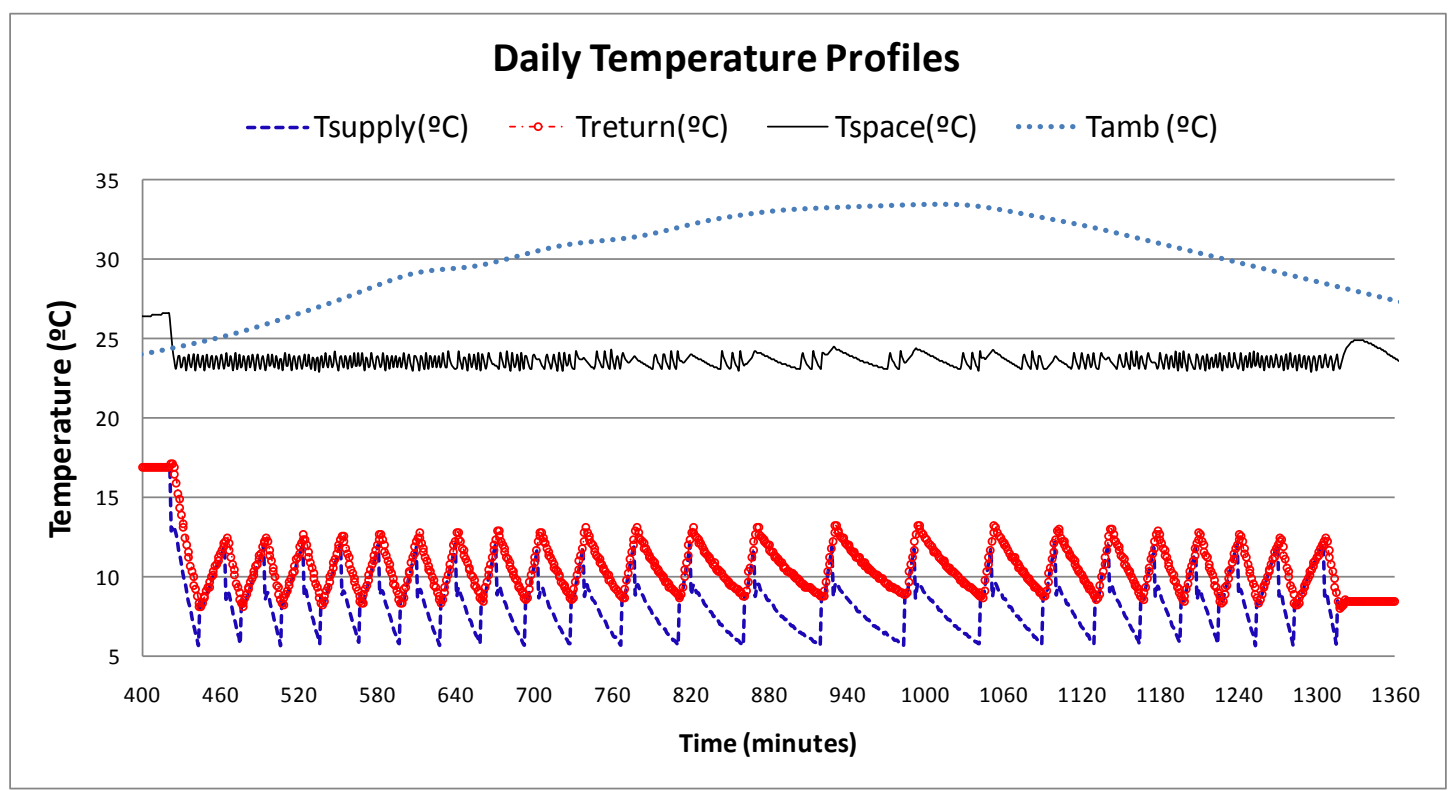

Fig. 9. Daily temperature profile - system mathematical model 


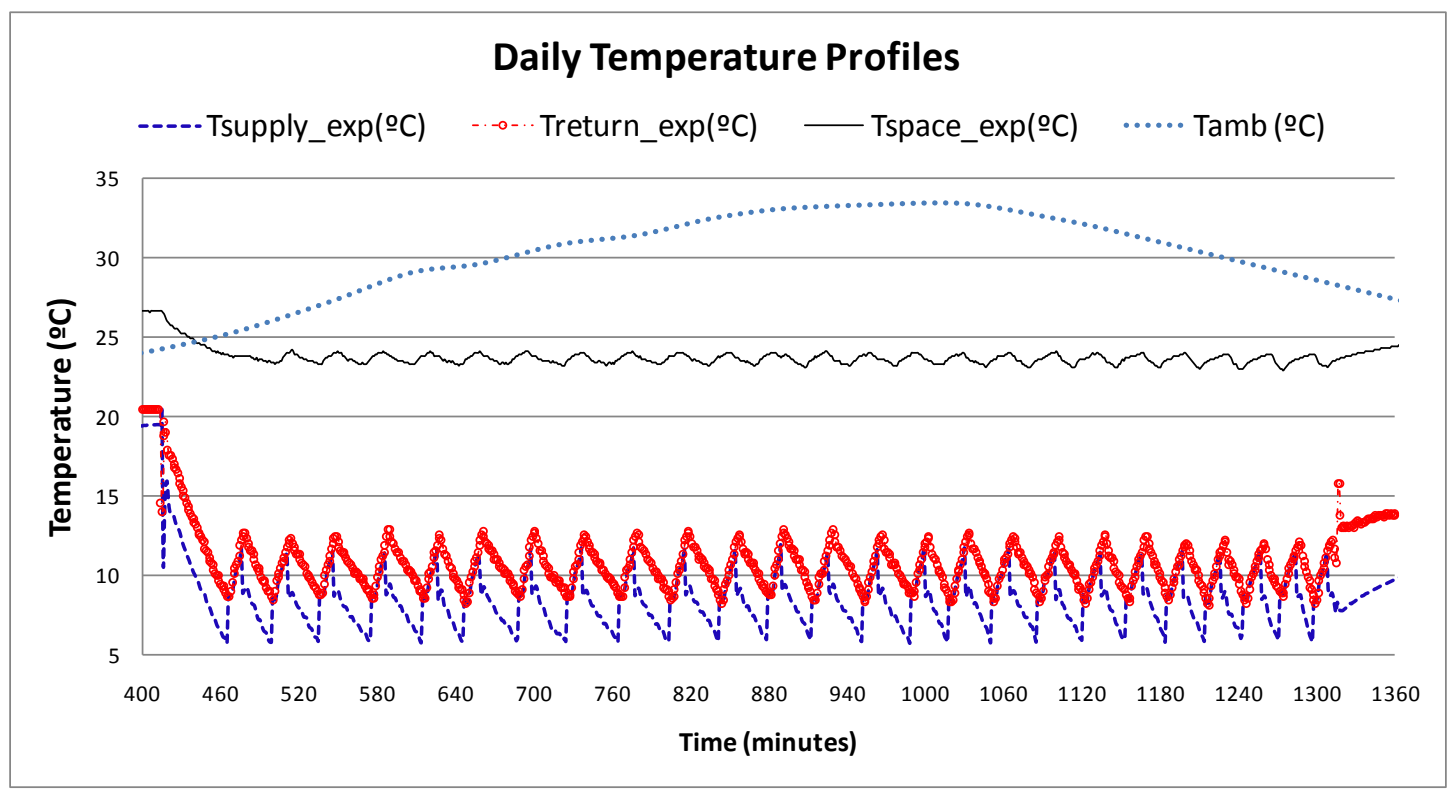

Fig. 10. Daily temperature profile - system experimental measurements 


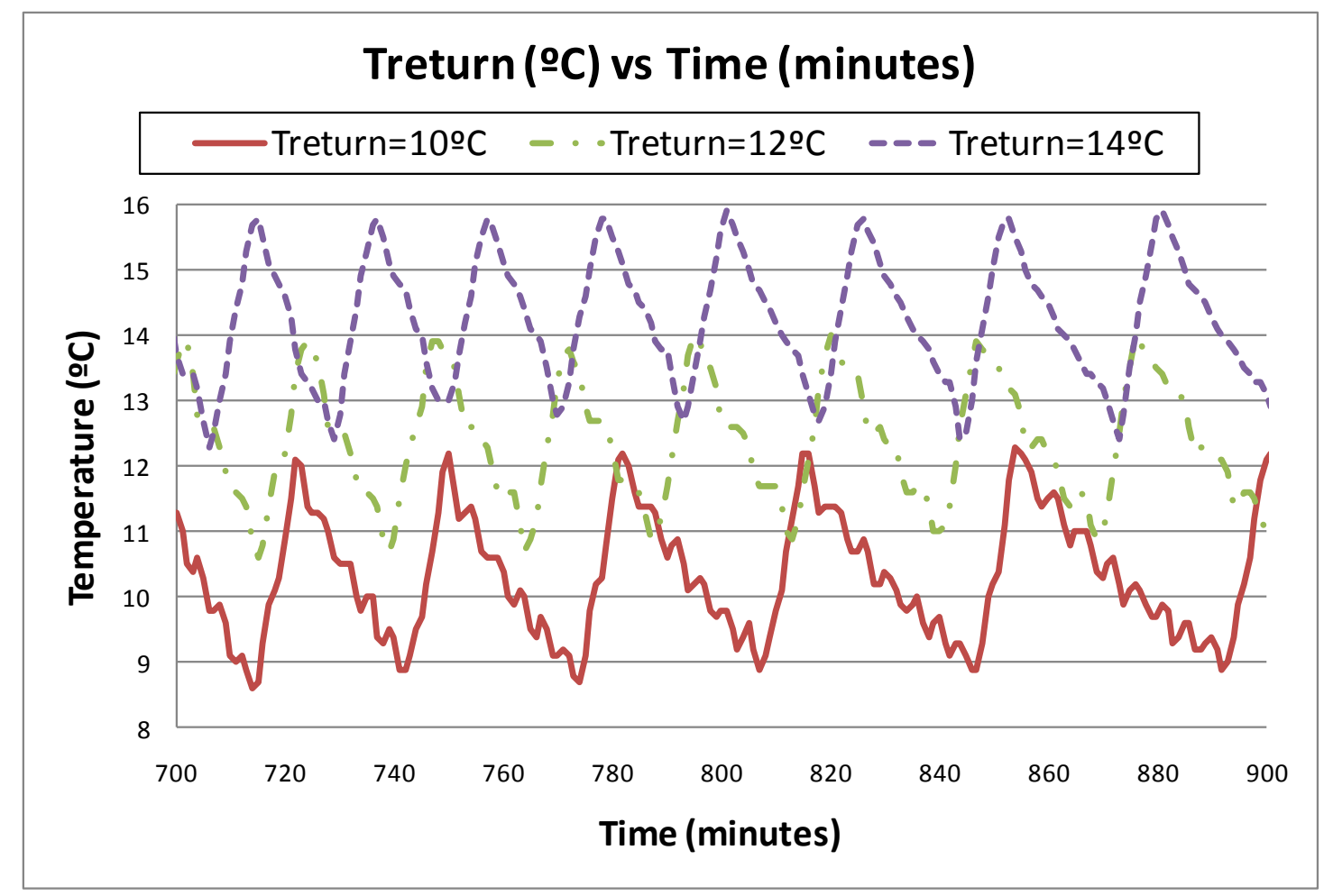

Fig. 11. Building water return temperature evolution 


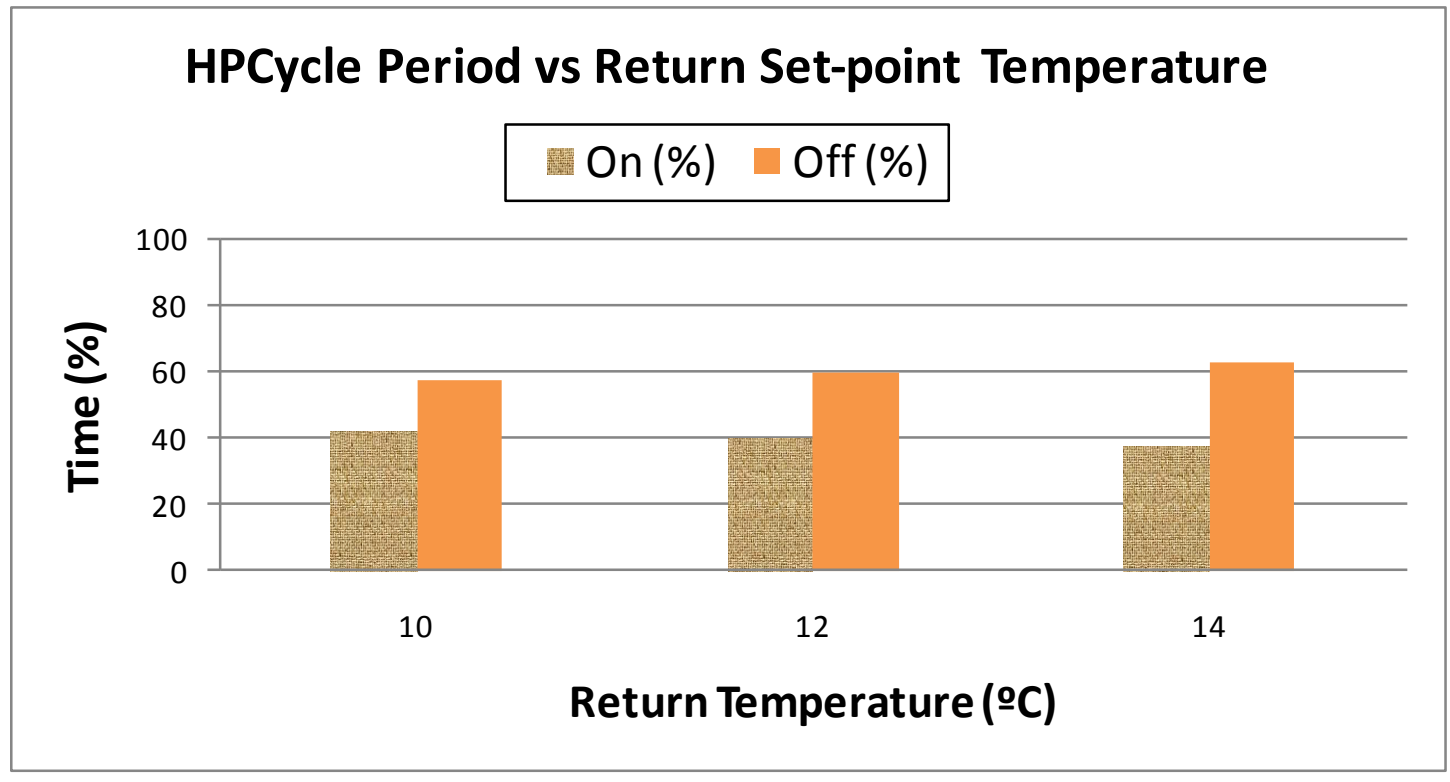

Fig. 12. Compressor cycle period data versus building water return temperatures 


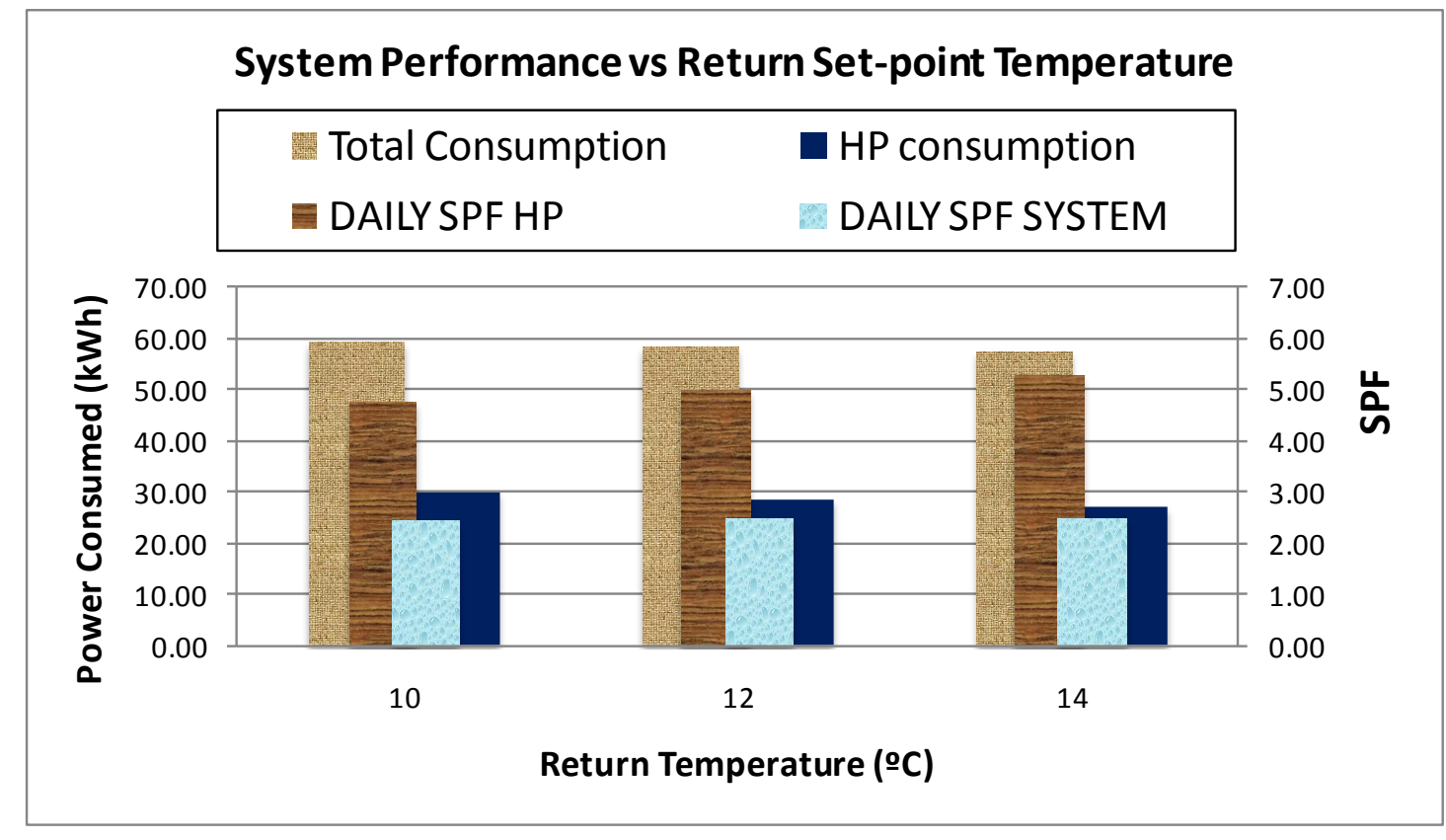

Fig. 13. Energy consumption and daily SPF versus building water return temperatures 


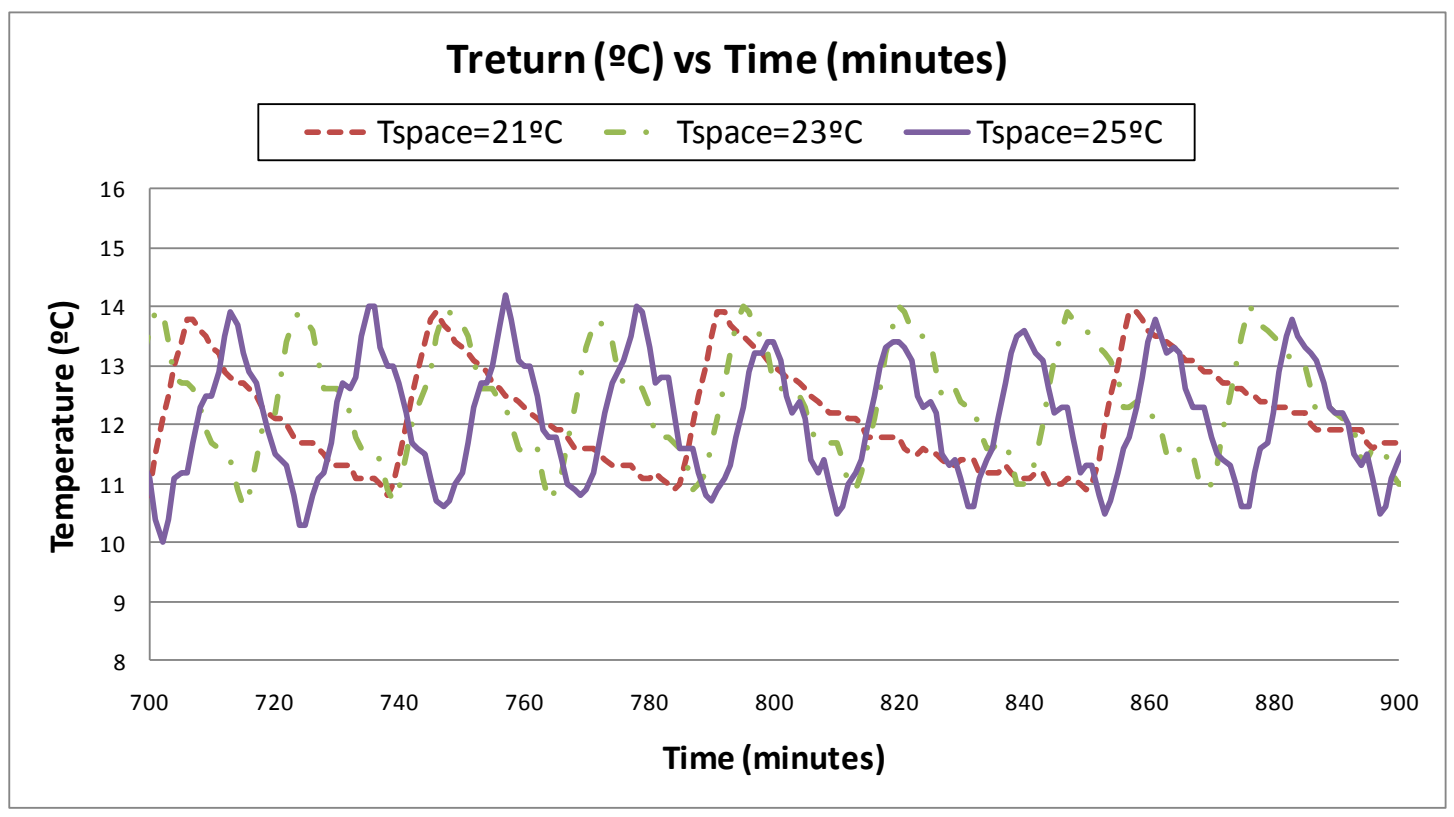

Fig. 14. Set-point control of space temperature 


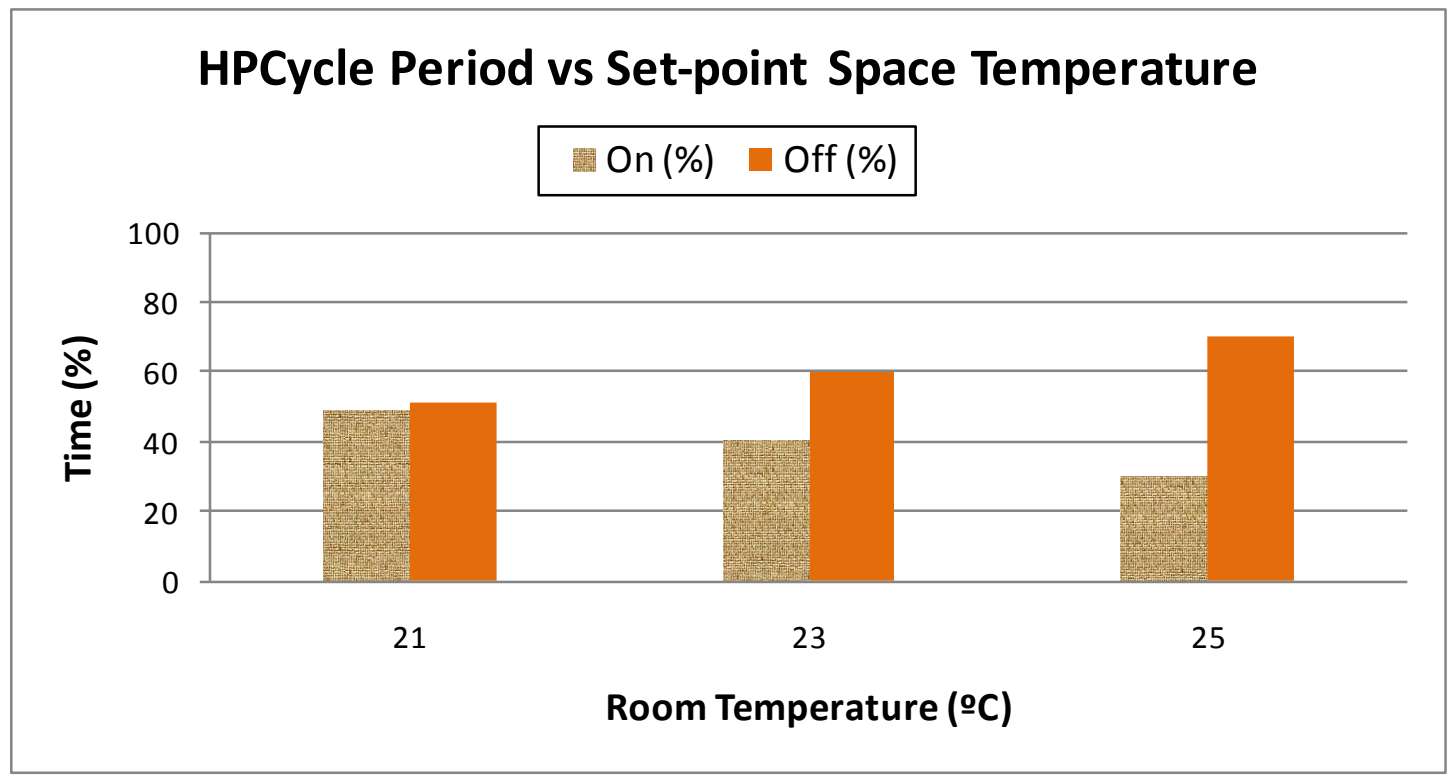

Fig. 15. Compressor cycle data 


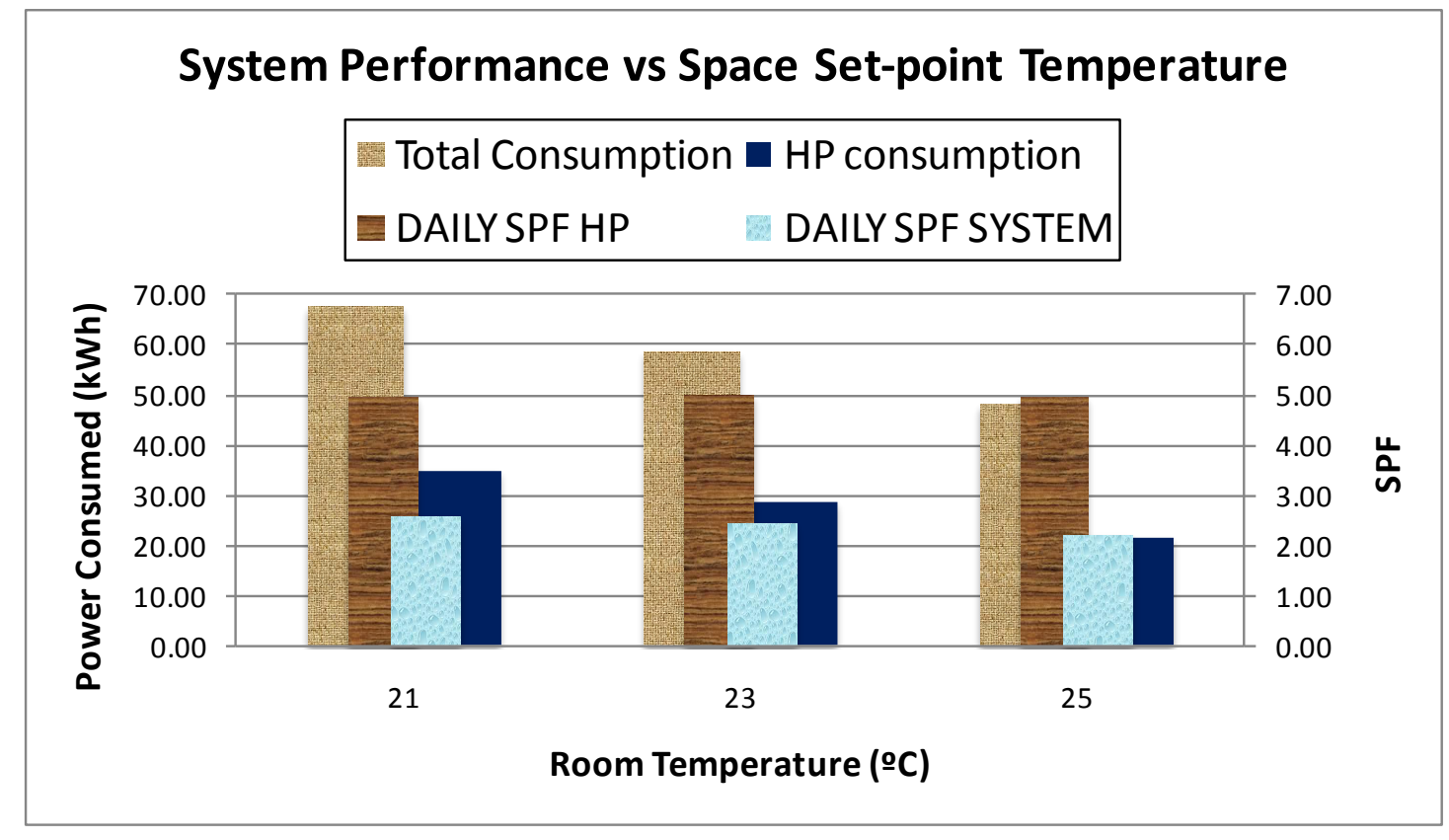

Fig. 16. Energy consumption and daily SPF as a function of space set-point temperature 


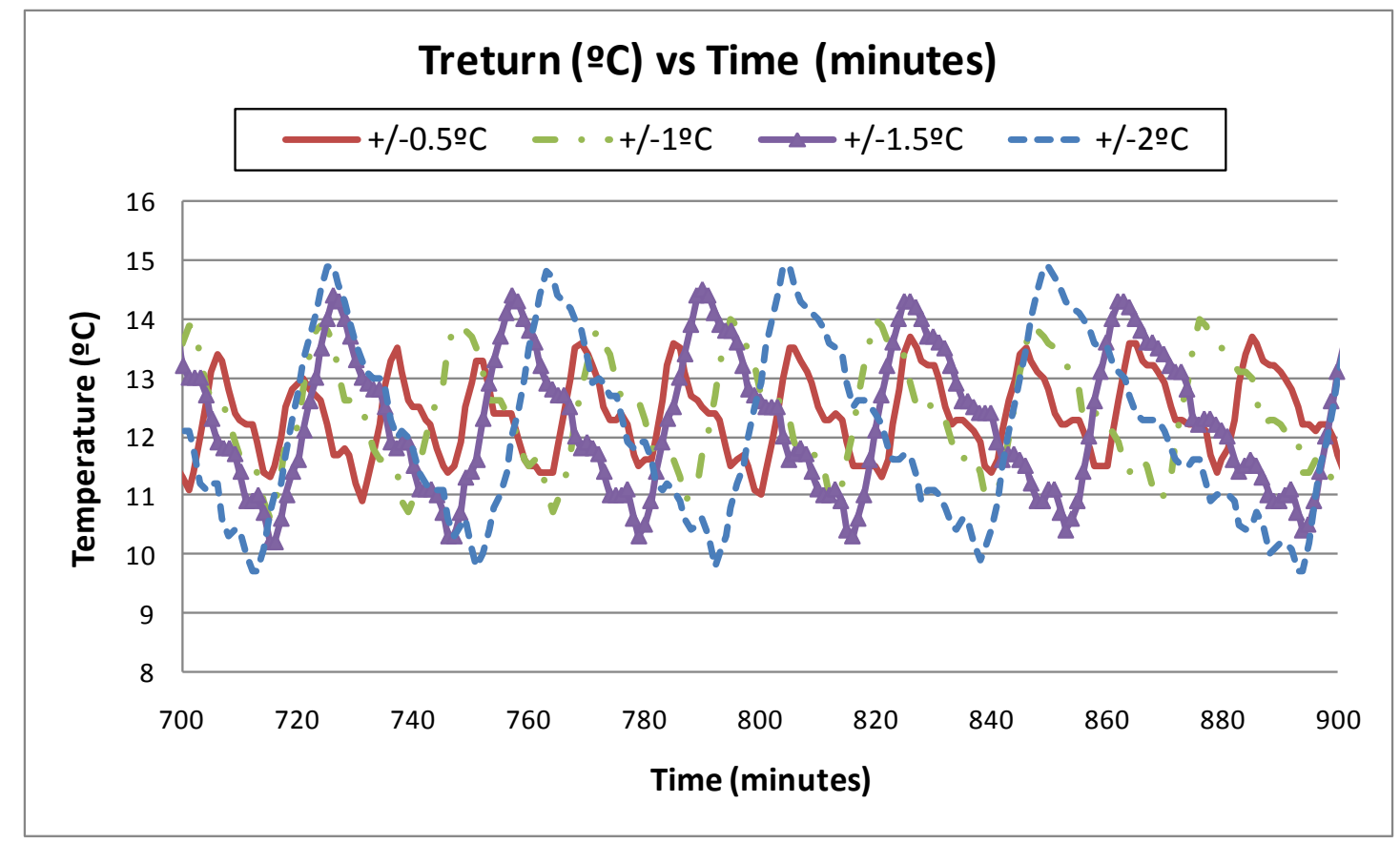

Fig. 17. Building return temperature as a function of return water bandwidth 


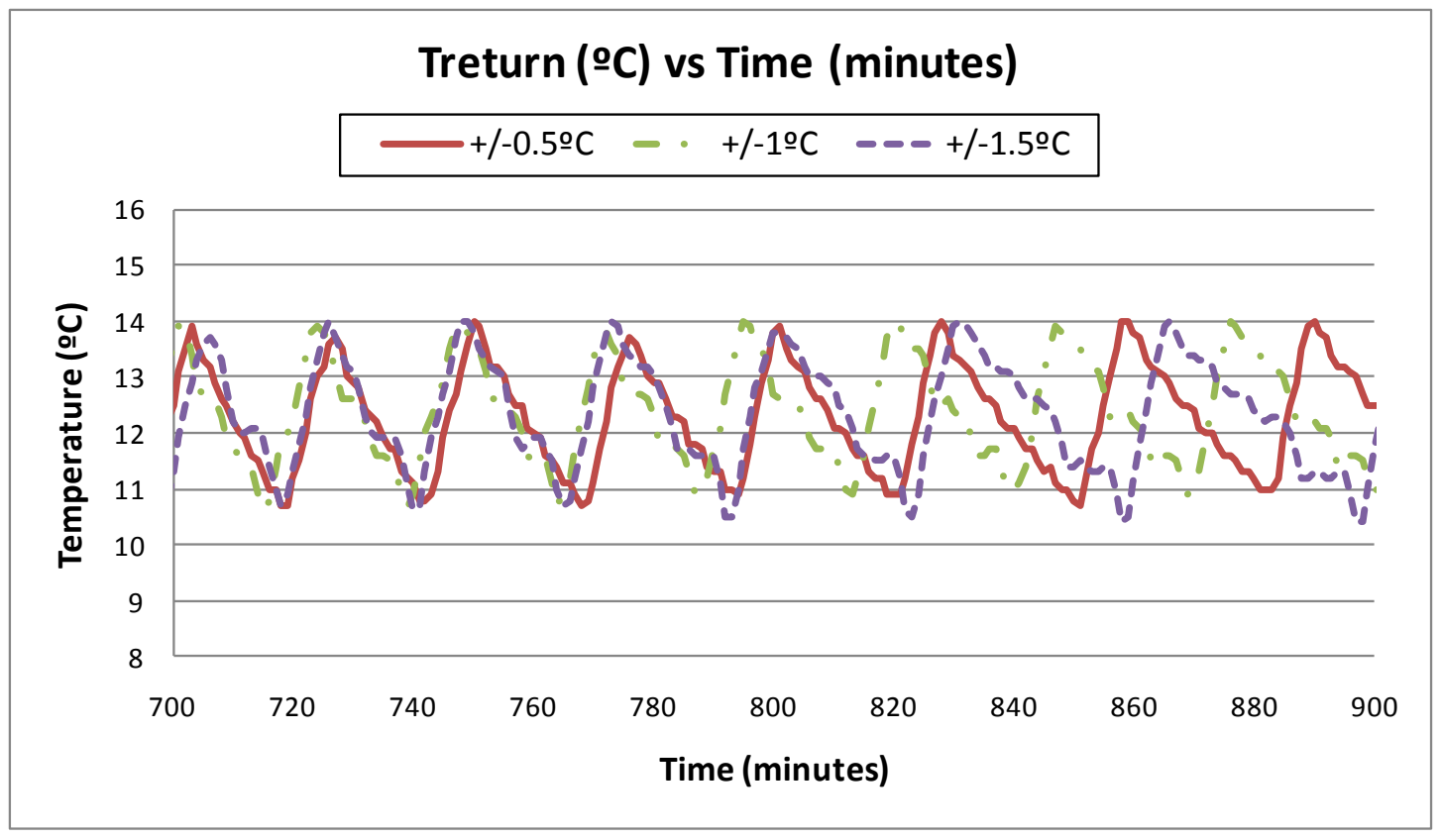

Fig. 18. Building return temperature for different space temperatures bandwidths 